\title{
A Tale of Regulatory Divergence: \\ Contrasting Transatlantic Policy Responses to the Alleged Role of Alternative Investment Funds in Financial Instability
}

\author{
Hossein Nabilou* \\ This article has been accepted for publication in Capital Markets Law Journal (C): [2017] Published by Oxford \\ University Press. All rights reserved.
}

\section{Key points}

- This article analyzes the regulatory measures adopted to address the potential contribution of hedge funds to financial instability in the U.S. and the EU in the wake of the Global Financial Crisis.

- The relevant provisions of the Dodd-Frank Act include two sets of direct regulatory measures. The first set of these measures addresses information problems, whereas the second set is intended to address potential too-big-to-fail problems by imposing prudential regulation on systemically important nonbank financial companies. The article then studies the Volcker Rule, as an indirect regulatory measure intended to address the potential systemic risk of hedge funds originating from their interconnectedness with Large Complex Financial Institutions (LCFIs).

- The second part of this article analyzes the European Directive on Alternative Investment Fund Managers and its attempt to address the potential contribution of hedge funds to financial instability.

- Despite the common driving forces of hedge fund regulation across the Atlantic, ultimate policy outcomes were significantly divergent. Primarily concerned with creating a single market for Alternative Investment Funds, EU regulators prioritized the EU passport mechanism, which engendered demand for investor protection and more stringent and direct regulatory measures.

- In contrast, the main concern in the U.S. remained to be addressing potential systemic risk of hedge funds. Such differential regulatory objectives gave birth to indirect regulation of hedge funds with a focus on their interconnectedness with LCFIs. This is mainly embedded in the provisions of the Volcker Rule; a rule whose absence is significantly palpable in the EU regime for regulating hedge funds.

Keywords: Dodd-Frank Act, Private Fund Act, Volcker Rule, Alternative Investment Fund Managers Directive, Alternative Investment Fund, Hedge Fund, Systemic Risk

\footnotetext{
* Faculty of Law, Economics and Finance, University of Luxembourg; LL.M., University of Pennsylvania Law School [hossein.nabilou@uni.lu]

This article was written during the author's stay at the EUROPAINSTITUT (Institute for European Global Studies) of the University of Basel. The author is grateful to the Institute for its generous funding and inspiring intellectual environment, and its staff's warm hospitality. The author also expresses his gratitude to Alessio Pacces for his comments on earlier drafts of this paper, to the participants in the Lecture Series of the EUROPAINSTITUT, the 5th Joint Seminar on the Future of Law \& Economics in Rotterdam, and the 31st Annual Conference of the European Association of Law and Economics (EALE) in Aix-en-Provence. Special thanks also go to the anonymous reviewers for their insightful comments. All errors are my own.
} 


\section{Introduction}

The global financial crisis (GFC) of 2007-09 harbingered sweeping changes in the regulatory environment of financial markets and institutions throughout the world. Although even prior to the GFC, financial regulatory authorities - under the pressing need for hedge fund regulation - outspokenly called for hedge fund regulation, ${ }^{1}$ such efforts faced stiff opposition from the hedge fund industry. Nonetheless, the enormity of the crisis and its economic and socio-political consequences were of such a magnitude that triggered a dramatic paradigm shift in financial regulation. This paradigm shift was markedly pronounced in the context of the hedge fund industry, the regulation of which was for long dormant on the regulatory agenda on both sides of the Atlantic. ${ }^{2}$

In the aftermath of the GFC, hedge funds were harshly criticized for destabilizing financial markets. ${ }^{3}$ Perceived as the legacy of the American laissez-faire capitalism, hedge funds faced pungent animosity from politicians of the continental Europe. ${ }^{4}$ Calling for their abolition, politicians demonized hedge funds as being 'crazy' and 'hellish', which "fall like a plague of locusts" over the companies, "devour everything, then fly on to the next one". ${ }^{5}$ In the midst of the financial crisis, hedge funds and private equity firms were further vilified as "'aggressive' gangs of 'speculators', bent on "snapping up firms, sacking workers and creaming off profits". ${ }^{6}$ Against such a hostile backdrop, the sweeping waves of regulatory reforms were

\footnotetext{
${ }^{1}$ In 2006, the U.S. Securities and Exchange Commission (SEC) Chairman, Christopher Cox, asserted that "[h]edge funds are not, should not be, and will not be unregulated." See Cox Christopher, Testimony Concerning the Regulation of Hedge Funds: Before the U.S. Senate Committee on Banking, Housing and Urban Affairs (2006) ${ }^{2}$ In 2004, the SEC concerned with hedge fund secrecy and fraudulent practices, in an attempt to rein in hedge fund advisers and with an eye to protecting unsophisticated investors, who indirectly invested in hedge funds through pension funds and other financial institutions, issued a rule (known as 'the Hedge Fund Rule'). Basically, in this rule making, the SEC required the hedge fund investment advisers with more than 15 clients (regardless of being individual or legal entities) to register with the SEC under the Investment Company Act. Nevertheless, in 2006, the U.S. Court of Appeals for the District of Columbia in Goldstein v. SEC found the rule arbitrary and accordingly vacated it. See Goldstein v. SEC, 451 F.3d 873, 884 (D.C. Cir. 2006). See also Anita K. Krug, 'Institutionalization, Investment Adviser Regulation, and the Hedge Fund Problem' (2011) 63 Hastings Law Journal 11

${ }^{3}$ However, there was a considerable disagreement on whether hedge funds were culprits or victims of the financial crisis. See Nicolas Papageorgiou and Florent Salmon, 'The Role of Hedge Funds in the Banking Crisis: Victim or Culprit' in Greg N. Gregoriou (ed), The Banking Crisis Handbook (The Banking Crisis Handbook, CRC Press, Taylor \& Francis Group 2010)

${ }^{4}$ Hedge funds are essentially considered as an Anglo-American phenomenon. It is estimated that the U.S. and the UK host almost 90 percent of hedge fund managers. See Andreas Engert, 'Transnational Hedge Fund Regulation' (2010) 11 European Business Organization Law Review 329364

${ }^{5}$ A statement quoted from Franz Müntefering, the then deputy chancellor of Germany. See Sebastian Mallaby, 'Hands off hedge funds' (2007) 86 Foreign Affairs 9192

${ }^{6}$, Battle of the Big Beasts: Mutual Suspicions and National Interests Underlie European Rows over Financial Regulation (2009).
} 
nigh, and before soon the waves of regulatory reforms engulfed the hedge fund industry on both sides of the Atlantic.

This paper is a comparative analysis of the post-crisis laws and regulations aimed to address the potential systemic implications of hedge funds in the U.S. and the EU, which together have the biggest share of the global hedge fund industry in terms of size and number. ${ }^{7}$ In addition to being the largest hub for hedge funds, the U.S. legal system is the cradle of the hedge fund industry, where it was born and fledged. ${ }^{8}$ The U.S. legal system also has the longest history of exposure to the risks posed by hedge funds both to investors and to the financial system. ${ }^{9}$ Therefore, it will come as no surprise to see that the U.S. regulatory regime is equipped with the most sophisticated regulatory measures for addressing the potential risks of the hedge fund industry.

However, the principal reason for comparing U.S. and EU hedge fund regulatory regimes is that they represent two main hedge fund regulatory philosophies, i.e., market-based and predominantly indirect approach adopted by the U.S. federal regulators, and direct government-regulation approach adopted by the EU regulatory authorities. ${ }^{10}$ Market-based

\footnotetext{
${ }^{7}$ The hedge fund industry is geographically concentrated. For example, in 2008, U.S. managers were managing about $75 \%$ of all hedge fund assets, whereas around $15 \%$ of assets were managed by European hedge funds. See David Stowell, Investment Banks, Hedge Funds, and Private Equity, vol 2nd (Elsevier 2013) 204. More recent data on geographic breakdown of hedge funds also confirm the dominance of North America followed by Europe. See, Report on the Third IOSCO Hedge Fund Survey, December 2015) 32. Although the size of the hedge fund industry in the EU is relatively small, it still is one of the popular jurisdictions for hedge funds, particularly because of the sources of investments coming from European institutional investors.

${ }^{8}$ The first hedge fund was created in the U.S. The term 'hedge fund' was coined by Carol J. Loomis in an article of 1966 discussing the structure and investment strategies of the investment vehicle originally created in 1949 by Alfred W. Jones See Carol J. Loomis, 'The Jones nobody keeps up with' (1966) 4 Fortune Magazine

${ }^{9}$ It was the failure of the Long-Term Capital Management (LTCM) in 1998 and Amaranth Advisors in 2006 that for the first time sparked controversies about hedge fund regulation due to systemic risk considerations. For a thorough overview of the collapse of LTCM, see Nicholas Dunbar, Inventing Money: The Story of Long-Term Capital Management and the Legends Behind It (Wiley 2000). See also Group President's Working, Hedge funds, leverage, and the lessons of long-term capital management (1999); Perry Mehrling, 'Minsky and Modern Finance: The Case of Long Term Capital Management' (2000) 26 The Journal of Portfolio Management 81; Franklin R. Edwards, 'Hedge funds and the collapse of long-term capital management' (1999) 13 Journal of Economic Perspectives 189; Stephen Cecchetti, 'A better way to organise securities markets' Financial Times (London October 4) Opinion <https://next.ft.com/content/fc9a4f48-72a8-11dc-b7ff-0000779fd2ac>

In contrast to the collapse of the LTCM, it is widely believed that the collapse of Amaranth Advisors did not have any systemic consequences. See William A. Roach Jr, 'Hedge Fund Regulation- "What Side of the Hedges Are You on?' (2009) 40 The University of Memphis Law Review 165 171; Roger Ferguson and David Laster, 'Hedge Funds and Systemic Risk' in France Banque de (ed), Financial Stability Review; Special Issue, Hedge Funds (Financial Stability Review; Special Issue, Hedge Funds, 2007) 51

${ }^{10}$ Robert J. Bianchi and Michael E. Drew, 'Hedge Fund Regulation and Systemic Risk' (2010) 19 Griffith Law Review 615 . Prior to the global financial crisis, there were, roughly speaking, two predominant approach to hedge fund regulation. The first approach was based on the trust in market forces to regulate hedge funds (also known as the market-making approach). The second approach was predominantly based on mistrust of the market forces and mainly relied on the government to take the lead in the hedge fund regulation (market-shaping approach). By and large, the former approach is identical to the Anglo-American approach to hedge fund regulation, and the
} 
approach to hedge fund regulation mainly relies on market participants, such as counterparties and creditors to reign in the risk-taking behavior of hedge funds. Needless to say, such an approach corresponds to the indirect-regulation approach to hedge funds. In contrast to the direct regulation, which is applied directly to a hedge fund entity itself or to the activities immediately performed by those hedge funds, the indirect regulation constitutes "market discipline-inspired regulatory measures targeting the creditors and counterparties of hedge funds (mainly, but not exclusively, their prime brokers and securities brokers). ${ }^{11}$ In this regard, the hedge fund regulatory system in Europe provides a counterfactual to the hedge fund regulatory system in the U.S. for the purposes of comparison.

This paper proceeds as follows. In the first section, the evolution of the post-crisis U.S. hedgefund regulatory framework is presented. This part focuses on the hedge fund-related provisions of the Dodd-Frank Wall Street Reform and Consumer Protection Act of 2010, particularly its Title IV, entitled "Regulation of Advisers to Hedge Funds and Others" the short title of which is the "Private Fund Investment Advisers Registration Act of 2010" (hereinafter, the Private Fund Act). The Private Fund Act is an attempt to deal with potential systemic risks of hedge funds by introducing transparency requirements. Then, the Volcker Rule, embedded in the Title VI of the Dodd-Frank Act, which is an attempt to reduce the systemic risk concerns about hedge fund activities through addressing problems of interconnectedness of hedge funds with banks is studied. Thereafter, the provisions of the Title I of the Dodd-Frank Act regarding the "Enhanced Supervision and Prudential Standards for Nonbank Financial Companies", which aim to address the systemic risk concerns of potentially too-big-to-fail hedge funds are discussed. In the second section, the EU Directive on Alternative Investment Fund Managers (AIFMD) and its subsequent implementing measures adopted to address the potential contribution of hedge funds to financial instability are reviewed. Followed by a conclusion highlighting the main findings of the paper, the third section presents an early assessment of the promises and pitfalls of hedge fund regulation on both sides of the Atlantic in mitigating their potential contribution to financial instability.

\footnotetext{
latter is similar to the continental European approach. See Lucia Quaglia, 'The 'Old' and 'New' Political Economy of Hedge Fund Regulation in the European Union' (2011) 34 West European Politics 665669

${ }^{11}$ Phoebus Athanassiou, Hedge Fund Regulation in the European Union: Current Trends and Future Prospects (Kluwer Law International 2009) 227. For an argument advocating indirect regulation of hedge funds vis-à-vis their direct regulation, see Hossein Nabilou and Alessio M. Pacces, 'The Hedge Fund Regulation Dilemma: Direct vs. Indirect Regulation' (2015) 6 William \& Mary Business Law Review
} 


\section{The Dodd-Frank Act and regulation of hedge funds}

The Dodd-Frank Act, passed on July 21, 2010, triggered massive regulatory reforms and resulted in a major overhaul of the regulatory environment of the U.S. financial markets. ${ }^{12}$ The U.S. regulation of hedge funds was mainly built upon indirect or market-discipline inspired regulation. Indirect regulation, which targets the counterparties of hedge funds, enhances market discipline on the hedge fund industry. In the U.S., the indirect regulation of hedge funds did not experience a dramatic change in the aftermath of the GFC. Even after the Private Fund Act, the U.S. hedge fund regulatory regime uses a mix of regulatory strategies, which heavily rely on the indirect regulation. The main market-discipline-enhancing regulatory reform in the U.S. involves registration and disclosure requirement studied below.

\subsection{Addressing information problems and transparency requirements}

The traditional mechanism for addressing information problems in the hedge fund industry is the imposition of requirements for registration and disclosure of certain information deemed to be necessary for assessing systemic risk. Since information problems in financial markets are perceived to be the main source of market failures, ${ }^{13}$ there is compelling theoretical and empirical evidence in favor of disclosure requirements. ${ }^{14}$ As is the case for systemic stability, the main reason for having a mandatory disclosure system for hedge funds is that such a system is indispensable for assessing systemic risk in financial markets. In the absence of mandatory

\footnotetext{
${ }^{12}$ To promote financial stability and address systemic risk, the Dodd-Frank Act introduces far-reaching provisions focused on the macro-prudential regulation of financial institutions. Indeed, the reforms introduced by this Act are only comparable, in extent, depth and pace to the financial regulatory overhaul of the post-Great Depression era in the U.S. See Viral V. Acharya and Matthew Richardson, 'Implications of the Dodd-Frank Act' (2012) 4 Annual Review of Financial Economics 12

It is estimated that the Act will result in approximately 400 rules and 87 studies before its full implementation. See Davis Polk, Dodd-Frank Rulemaking Progress Report: Progress as of June 1, 2011 (2011) So far, a majority of regulations have been proposed and passed. See Davis Polk Regulatory Tracker, Dodd-Frank Progress Report: October 2013 (2013)

${ }^{13}$ The main source of market failures rooted in information problems in the marketplace originates from the 'lemons problem'. See George A. Akerlof, 'The Market for "Lemons": Quality Uncertainty and the Market Mechanism' (1970) 84 The Quarterly Journal of Economics 488

${ }^{14}$ See Robert E. Verrecchia, 'Essays on Disclosure' (2001) 32 Journal of Accounting and Economics 97 132; Michael J. Fishman and Kathleen M. Hagerty, 'Mandatory Versus Voluntary Disclosure in Markets with Informed and Uninformed Customers' (2003) 19 Journal of Law, Economics, \& Organization 45; C. Leuz and P. Wysocki, 'Economic Consequences of Financial Reporting and Disclosure Regulation: A Review and Suggestions for Future Research' (2008). For more information on the advocacy of the mandatory disclosure based on positive externalities and free-rider problem, see Anat R. Admati and Paul Pfleiderer, 'Forcing Firms to Talk: Financial Disclosure Regulation and Externalities' (2000) 13 Review of Financial Studies 479 512; M. B. Fox, 'Retaining Mandatory Securities Disclosure: Why Issuer Choice Is Not Investor Empowerment' (1999) 85 Virginia Law Review 1335
} 
disclosure, regulators' ability to acquire reliable data - upon which the regulatory strategies and instruments are to be built - would be severely impaired. ${ }^{15}$

Prior to the recent regulatory reforms, hedge funds were operating under the regulatory radar and were not required to register with the federal regulatory agencies in the U.S. ${ }^{16}$ One of the most notable and controversial post-crisis changes to the financial regulation in the U.S. is the reform in the regulatory environment of hedge funds and private equity funds. ${ }^{17}$ The Private Fund Act modified the investment adviser registration and exemption regime under the Investment Advisers Act of $1940^{18}$ and imposed registration and reporting requirements on hedge funds and private equity funds.

In addition to eliminating the private adviser exemption, the Private Fund Act introduces new regulations in connection with the custody of accounts, requires changes to the definition of accredited investors, lays the statutory groundwork for the possible establishment of selfregulatory organization for private funds, requires certain data, reports and disclosure by private funds, calls for certain disclosure and consultation with the Financial Stability Oversight Council (FSOC), sets out certain rules about the examination and confidentiality of books and records of hedge funds and private equity funds, and requires collection of systemic risk data. ${ }^{19}$

\footnotetext{
${ }^{15}$ Although there were voluntary disclosure mechanisms in place even prior to recent financial regulatory overhaul and some hedge funds opted for disclosure, the disclosed data were of limited use, because of their embedded statistical biases due to the voluntary nature of the disclosure requirements. For a detailed discussion of the impact of the absence of mandatory disclosure regime in the hedge fund industry on the quality of data, see Vikas Agarwal and Narayan Y. Naik, 'Hedge Funds' (2005) now Publishing INC, Hanover, MA Foundations and Trends in Finance 55

${ }^{16}$ In the UK, in addition to mandatory registration of hedge funds with the former Financial Services Authority (FSA), there was a voluntary disclosure system in place through the Hedge Funds as Counterparties Survey (HFACS) mechanism. However, the AIFMD set a step forward and required mandatory reporting by hedge funds and subjected them to the inspections by the competent authorities. See James Buckley and David Howarth, 'Internal Market: Regulating the So-Called "Vultures of Capitalism" (2011) 49 Journal of Common Market Studies 123139

${ }^{17}$ The Dodd-Frank Act is basically built upon the experiences of the Long-Term Capital Management (LTCM) meltdown and the following study by the President's Working Group (PWG). More recently, on February 22, 2007, the PWG published the "Agreement Among PWG and U.S. Agency Principals on Principles and Guidelines Regarding Private Pools of Capital". This report sketches the broad principles related to control of systemic risk as well as investor protection. The approach mainly rests upon 'market discipline', which is supplemented by compliance with the 'industry sound practices'. This approach expresses its interests in principles-based regulation of hedge funds. See John Hunt, 'Hedge Fund Regulation: The President's Working Group Committees' Best Practices Reports: Raising the Bar But Missing Risks' (2008) Available at SSRN 12798705 Accordingly, this report calls for greater market discipline harnessed by light-touch regulation. See U.S. Department of the Treasury, Agreement Among PWG and U.S. Agency Principals on Principles and Guidelines Regarding Private Pools of Capital (2007)

1815 U.S.C. $\S 80 \mathrm{~b}-1(21)$

${ }^{19}$ See generally 15 U.S.C. $\S 80$ b.
} 
Section 402 of the Private Fund Act characterizes hedge funds as 'private funds' under the Investment Advisers Act, which regulates investment advisers doing business of advising and managing investment funds in the U.S. Under the previous regime - repealed by the Private Fund Act - the Investment Advisers Act excluded certain investment advisers from the application of its requirements. Under that regime, hedge fund advisers were exempt from registration, provided that they advise 15 or fewer clients ('the Private Adviser Exemption'). Section 203(b)(3) of the Investment Advisers Act as amended by the Dodd-Frank Act, no longer exempts advisers with such qualifications.

Under the previous regulatory regime, hedge funds were under virtually no obligation of record-keeping and reporting to the public, regulators and investors, unless their investment triggered the application of certain regulations. This posed questions about the feasibility of verification of hedge funds' risk assessment and due diligence towards their investors under their fiduciary duties. U.S. regulators decided to intervene and address the opacity problem in the hedge fund industry by choosing a qualified disclosure system, i.e., disclosure system with certain levels of confidentiality. This system was a compromise and a balance between competing interests of hedge funds, their investors, counterparties, regulators, and the taxpayers at large.

The Private Fund Act requires hedge fund managers acting solely as an adviser to private funds with $\$ 150$ million or more in Assets under Management (AUM) ${ }^{20}$ to register with the Securities and Exchange Commission (SEC). ${ }^{21}$ Therefore, for the managers whose AUM exceed the \$150-million threshold, the Act abolishes the private investment adviser exemption in the Investment Advisers Act and the Goldstein v. SEC decision. ${ }^{22}$ An adviser not registered with the SEC is required to register with the State where it has the principal office if the State's law so requires. In short, under the new rules, unless private fund advisers have at least $\$ 150$ million in AUM, they are not required to register with and report to the SEC. ${ }^{23}$

\footnotetext{
${ }^{20}$ The total market value of the assets managed by an investment company on behalf of its investor is called AUM.

${ }^{21} 15$ U.S.C. $\S 80 \mathrm{~b}-3(\mathrm{~m})(1)$.

${ }^{22}$ The SEC has proposed a rule that requires hedge funds with more than \$1 billion in AUM to provide quarterly reports using the Form PF. "See, SEC Proposes Private Fund Systemic Risk Reporting Rule, (U.S. Securities and Exchange Commission 2011); See also Goldstein v. SEC, 451 F.3d 873 (D.C. Cir. 2006).

${ }^{23} 15$ U.S.C. $\S 80 \mathrm{~b}-3(\mathrm{~m})(1)$. The Act confers powers to the SEC to tailor the registration and examination procedures with respect to the investment advisers of mid-sized private funds, taking into account the governance and the investment strategy of such funds to determine whether they pose systemic risk. 15 U.S.C. $\S 80 \mathrm{~b}-3(\mathrm{n})$. See also James F. Koehler, 'Impact of the Dodd-Frank and Registration Acts of 2010 on Investment Advisers' (2011) 13 Duquesne Business Law Journal 29
} 


\subsection{Contingent direct regulation of hedge funds}

The provisions of the Title I of the Dodd-Frank Act involve the "enhanced supervision and prudential standards for nonbank financial companies" to which this paper refers as "contingent direct regulation'. These contingent provisions, which are potentially applicable to hedge funds, aim at imposing prudential standards on the Systemically Important Nonbank Financial Companies (SINBFCs). The Dodd-Frank Act grants the authority to the FSOC to determine whether a non-bank financial company, which among other things includes hedge funds, shall be supervised by the Federal Reserve (Fed) and be subject to prudential standards. Such a determination should be made on a nondelegable basis and by a vote of not fewer than twothirds of the voting members including the affirmative vote of the Chairperson of the FSOC. ${ }^{24}$ If the FSOC determines that the "material financial distress at the U.S. nonbank financial company, or the nature, scope, size, scale, concentration, interconnectedness, or mix of the activities of the U.S. nonbank financial company, could pose a threat to the financial stability of the United States", it will make the company subject to the prudential supervision of the Fed. $^{25}$

Therefore, the FSOC will designate a Nonbank Financial Company (NBFC) as a SINBFC if either of the following two standards is met. Under the first standards, a NBFC will be subject to the prudential standards of the Fed if the FSOC determines that the material financial distress at the NBFC could pose a threat to the U.S. financial stability. Under the second standard, a NBFC will be designated as systemically important "if the nature, scope, size, scale, concentration, interconnectedness, or mix of the activities" of the NBFC could pose a threat to U.S. financial stability. ${ }^{26}$ The Dodd-Frank Act also lists ten considerations for the FSOC to

\footnotetext{
${ }^{24}$ The Secretary of the Treasury is the chairperson of the FSOC.

${ }^{25} 12$ U.S.C. $\S 5323$ (a)(1). See also 12 CFR § 1310.10

${ }^{26} 12$ CFR $\S 1310$, Appendix A.
} 
take into account while making such an assessment. ${ }^{27}$ Furthermore, the FSOC has discretion to take account of any other risk-related factors which it deems appropriate. ${ }^{28}$

Once a company is designated as a SINBFC, it will be subject to the prudential regulation of the Fed. Furthermore, the FSOC has the discretion to recommend that the Fed strengthen the prudential standards on a particular SINBFC and apply standards that are "more stringent than those applicable to other nonbank financial companies and bank holding companies that do not present similar risks to the financial stability of the United States". ${ }^{29}$

In April 2012, the FSOC promulgated the final rules expounding the process of designating a NBFC as systemically important. ${ }^{30}$ These rules introduce a three-stage process of evaluation in designating a NBFC as a SINBFC. The firms meeting the first stage requirements pass on to the next stage, and the firms meeting the second stage requirements pass on to the third stage. A non-bank financial company passes on the first stage if its total consolidated assets are $\$ 50$ billion or more and it meets or exceeds one of the following thresholds:

- $\$ 30$ billion in gross notional credit default swaps (CDSs);

- $\$ 3.5$ billion in derivatives liabilities;

- $\$ 20$ billion in total debt outstanding;

- a leverage ratio of 15 to 1 ;

${ }^{27}$ See 12 U.S.C. $\S 5323(\mathrm{a})(2)$.

The considerations for designating the non-bank financial company as systemically important include, inter alia,

1. the extent of leverage;

2. off-balance sheet exposures;

3. the extent and nature of the transactions and relationships of the company with other significant NBFCs and significant bank holding companies (BHCs);

4. "the importance of the company as a source of credit for households, businesses, and State and local governments and as a source of liquidity for the United States financial system";

5. whether the funds are managed or owned by the company;

6. the nature, scope, size, scale, concentration, interconnectedness, and mix of the activities of the company;

7. whether the company is already regulated by one or more financial regulatory agencies;

8. the amount and the nature of the financial assets of the company;

9. the amount and types of liabilities of the company including the degree of reliance on short-term funding; and

10. any other risk related factors that the FSOC deems necessary. See 12 U.S.C. $\S 5323$ (a)(2); 12 CFR $\S$ 1310.11

${ }^{28} 12$ U.S.C. $5323(\mathrm{a})(2)(\mathrm{K})$ and $(\mathrm{b})(2)(\mathrm{K})$. An analytical framework has been developed by the FSOC, which puts all relevant factors into six categories: size, interconnectedness, substitutability, leverage, liquidity risk and maturity mismatch, and existing regulatory scrutiny. 12 CFR $\S 1310$, Appendix A.

${ }^{29} 12$ U.S.C. $\S 5325(\mathrm{a})(1)$.

${ }^{30} 12$ CFR $\$ 1310$. 
- a ratio of total debt outstanding with maturity of less than 12 months to total consolidated assets of 0.1 (10 percent). ${ }^{31}$

In stage 2, the companies identified in the first stage will be analyzed. In this stage, in contrast to the quantitative thresholds of the first stage, the FSOC uses a wide range of quantitative and qualitative industry and firm-specific factors, which are available to it through public and regulatory resources, to evaluate the risk profile of the individual company. Following the stage 2, the NBFCs identified for additional review will receive notice of being considered for a 'Proposed Determination' and pass to the third stage in which they will be subject to an indepth evaluation. ${ }^{32}$

In Stage 3, the FSOC will assess the potential risks of the company based on the information, which is directly collected from the company, and on the public and regulatory information acquired in the process of the first and second stages. It is in this stage that the NBFC can be designated as SINBFC by two-thirds of the votes of the FSOC members including an affirmative vote of the Secretary of the Treasury. ${ }^{33}$ Once a hedge fund is designated as a SINBFC, the Fed upon the recommendations of the FSOC will establish prudential regulations for such a fund. ${ }^{34}$ The Fed may, but is not required to, establish additional prudential standards such as contingent capital requirement, enhanced public disclosures, short-term debt limits, and other standards that the Board of Governors, on its own or pursuant to recommendations of the FSOC, determines are appropriate. ${ }^{35}$ To date, the FSOC designated four firms as

${ }^{31} 12$ CFR $\S 1310$.

32 CFR $\$ 1310$.

${ }^{33} 12$ CFR $\$ 1310$.

${ }^{34}$ These prudential standards should include:

1. risk-based capital requirements and leverage limits unless the Board of Governors, in consultation with the FSOC, determines that such requirements are not appropriate;

2. liquidity requirements;

3. overall risk-management requirements;

4. resolution plan and credit exposure report requirements; and

5. concentration limits. See 12 U.S.C. $\S 5365(b)$.

3512 U.S.C. $\S 5365$ (b). In short, according to the above discussion, from the standpoint of being systemically important, hedge fund can be put into three categories:

1. Hedge funds that are highly unlikely to be considered as systemically important. These hedge funds are not required to register with the federal regulatory agencies. However, the state registration requirements apply.

2. Hedge funds exceeding certain threshold ( $\$ 150$ million in AUM) should register with the SEC. It is likely that these hedge funds contribute to the financial stability through their interconnectedness with LCFIs or through herding behavior. Hence they are required to register with the SEC and disclose certain information thereto.

3. Hedge funds designated as SINBFCs. These hedge funds are considered as systemically important because of their size and the amount of leverage. Needless to say, these hedge funds can have serious systemic implications for financial markets through their size, potential interconnectedness or herding behavior. Thus, they are subject to the prudential regulations of the Fed. 
SINBFC including American International Group, Inc., (AIG), General Electric Capital Corporation, Inc. (GE Capital), Prudential Financial, Inc. (Prudential), and MetLife, Inc. (MetLife). ${ }^{36}$ MetLife could successfully challenge the constitutionality of its designation ${ }^{37}$ and overturn it on the grounds of arbitrary and capriciousness. ${ }^{38}$

\subsection{The Volcker Rule}

The Volcker Rule- embedded in the Section 619 of the Title VI of the Dodd-Frank Act $^{39}$ is a structural regulation, ${ }^{40}$ which aims to address three problems in financial markets: managing systemic risk by addressing the contagion channels between hedge funds and banks, managing conflicts of interest where banking entities engage in proprietary trading and investment in or sponsorship of hedge funds, and limiting the transfer of government subsidies from depository institutions to private funds (cross-subsidization of private funds by depository institutions). These prime objectives are pursued by adopting provisions, which prohibit banking entities (depository institutions) from engaging in proprietary trading and investment in or sponsorship of hedge funds and private equity funds.

Since the greatest systemic risk concerns about the hedge fund industry originates from their interconnectedness with banks, ${ }^{41}$ the Volcker Rule (bearing the name of its mastermind, Paul Volcker) is an attempt to indirectly regulate hedge funds through direct regulation of banks, which often play the role of hedge fund counterparties, creditors, sponsors, investors, or prime brokers. The primary goal of this provision is to prohibit the banking system from speculative trading with the banks' own capital, mitigate the potential conflicts of interest between banking entity and its customers, and reduce the risks to the banks and non-bank financial companies designated as SINBFCs, which are subject to supervision by the Fed. ${ }^{42}$

\footnotetext{
${ }^{36}$ Financial Stability Oversight Council, Designations (2016) $<$ https://www.treasury.gov/initiatives/fsoc/designations/Pages/default.aspx\#nonbank>

${ }^{37}$ MetLife Inc. v. Financial Stability Oversight Council, 15-cv-00045, U.S. District Court, District of Columbia

${ }^{38}$ See Robert C Hockett, 'Oversight of the Financial Stability Oversight Council: Due Process and Transparency in Non-Bank SIFI Designations' (2015) Available at SSRN 2796331

3912 U.S.C. $\$ 1851$. The Volcker Rule is also called the Glass-Steagall lite.

${ }^{40}$ John C. Coates IV, 'The Volcker Rule as structural law: implications for cost-benefit analysis and administrative law' (2015) 10 Capital Markets Law Journal 447

${ }^{41}$ This problem in especially pronounced in the run-up to the GFC, when the collapse of two of Bear Stearns' hedge funds in the spring of 2007 imposed losses on their systemically important parent company. See Darrell Duffie, 'The Failure Mechanics of Dealer Banks' (2010) 24 The Journal of Economic Perspectives 51 59. For a detailed overview of how the failure of the Bear Stearns' hedge funds affected the firm, See William D Cohan, House of cards: A tale of hubris and wretched excess on Wall Street (Anchor 2010)

${ }^{42}$ Financial Stability Oversight Council, Study \& Recommendations on Prohibitions on Proprietary Trading \& Certain Relationships with Hedge Funds and Private Equity Funds (2011) 15
} 
The Volcker Rule is a two-pronged provision. It introduces restrictions on proprietary trading ${ }^{43}$ as well as prohibitions on the investments in and sponsorship of hedge funds by banking entities. ${ }^{44}$ First, the article studies the Volcker Rule's prohibition of proprietary trading, then, it turns to analyzing the Volcker Rule' prohibitions of investment and sponsorship of hedge funds and private equity funds by banking entities in light of its stated objectives.

\subsubsection{Prohibitions on proprietary trading}

Proprietary trading offers attractive opportunities for banks in terms of potential trading profits. It is reported that in $2004,75 \%$ of the $\$ 6.7$ billion of Goldman's earnings before tax came from trading and investments. ${ }^{45}$ However, the losses from proprietary trading played a role in putting LCFIs, such as Lehman Brothers, Merrill Lynch, Morgan Stanley, and Citigroup, at risk in the run-up to the GFC. ${ }^{46}$ In addition, mixing risky security holdings with economically important financial intermediation within banks was perceived as one of the major causes of the recent financial crisis. ${ }^{47}$ The proprietary trading provisions of the Volcker Rule prohibit a banking entity $^{48}$ from engaging in trading activities as principal to profit from the near-term price movements. $^{49}$

However, in order not to interfere with the smooth functioning of financial markets, the Volcker Rule exempts certain activities from the application of its prohibitions by accommodating certain exceptions as 'permitted activities'. ${ }^{50}$ These permitted activities mainly involve banking activities perceived to be ultimately beneficial to the broader economy and necessary for maintaining the safety and soundness of financial institutions. ${ }^{51}$ These permitted

\footnotetext{
${ }^{43}$ The term 'proprietary trading' when used with respect to a banking entity or a SINBFC means "engaging as a principal for the trading account of [a] banking entity or [a SINBFC] in any transaction to purchase or sell, or otherwise acquire or dispose of, any security, any derivative, any contract of sale of a commodity for future delivery, any option on any such security, derivative, or contract, or any other security or financial instrument that the appropriate Federal banking agencies, the [SEC], and the [CFTC] may ... determine." 12 U.S.C. § 1851(h)(4). ${ }_{45}^{44} 12$ U.S.C. $\S 1851$.

45 Justin Fox, 'Goldman: We Run Wall Street' CNNMoney (may 2005) $<$ http://money.cnn.com/magazines/fortune/fortune_archive/2005/05/16/8260146/>

${ }^{46}$ See R. Rex Chatterjee, 'Dictionaries Fail: The Volcker Rule's Reliance on Definitions Renders It Ineffective and a New Solution Is Needed To Adequately Regulate Proprietary Trading' (2011) 8 Brigham Young University International Law \& Management Review 33 47; Office United States Government Accountability, Proprietary Trading: Regulators Will Need More Comprehensive Information to Fully Monitor Compliance with New Restrictions When Implemented (2011)

${ }^{47}$ Acharya and Richardson, 'Implications of the Dodd-Frank Act'

${ }^{48}$ For the definition of a banking entity, see 12 U.S.C. $\S 1851(\mathrm{~h})(1)$.

4912 U.S.C. $\$ 1851(\mathrm{a})$ and $(\mathrm{h})(4)$.

${ }^{50} 12$ U.S.C. $\S 1851(\mathrm{~d})(1)$.

${ }^{51}$ Council, Study \& Recommendations on Prohibitions on Proprietary Trading \& Certain Relationships with Hedge Funds and Private Equity Funds
} 
activities, which involve taking principal risk, cover a range of activities at the core of banking functions, such as market making, ${ }^{52}$ underwriting, ${ }^{53}$ risk-mitigating hedging, ${ }^{54}$ transactions on behalf of customers, ${ }^{55}$ and transactions in government securities. ${ }^{56}$

The permitted activities are in turn subject to so-called prudential 'backstops ${ }^{57}$ In other words, the Volcker Rule makes its exceptions subject to exceptions as a fallback strategy. These exceptions would require banning permitted activities if they result in material conflicts of interest between the banking entity and it clients, customers or counterparties, a material exposure by the banking entity to high-risk assets or high-risk trading strategies, pose a threat to safety and soundness of the banking entity, or pose a threat to financial stability of the United States. $^{58}$

\subsubsection{Restrictions on investment in hedge and private equity funds and prohibitions on} covered transactions

The Volcker Rule provisions also prohibit a banking entity from investing in, or having certain relationships with hedge funds and private equity funds, as defined under the exclusions of the Investment Company Act of $1940 .^{59}$ These restrictions prohibit a banking entity from acquiring or retaining any equity, partnership, or other ownership interest in or sponsoring a hedge fund or a private equity fund. ${ }^{60}$ The Volcker Rule's prohibitions on investment in hedge and private equity funds and its prohibitions on proprietary trading basically share the same objectives. Namely, not only do these restrictions intend to eliminate the federal support for speculative investing strategies of banking entities with their own capital, but also they intend to reduce the conflicts of interest between a banking entity and its customers. In the meantime, they strive to reduce the risk to banking entities and SINBFCs which are supervised by the Fed. ${ }^{61}$

\footnotetext{
5212 U.S.C. $\S 1851(\mathrm{~d})(1)(\mathrm{B})$.

53 12 U.S.C. $\S 1851(\mathrm{~d})(1)(\mathrm{B})$.

${ }^{5} 12$ U.S.C. $\S 1851(\mathrm{~d})(1)$.

5512 U.S.C. $\$ 1851(\mathrm{~d})(1)(\mathrm{D})$.

${ }^{56}$ Further exemptions include transacting in government securities, certain insurance activities, investments in small business investment companies, public welfare investments, certain qualified rehabilitation expenditures under federal or state tax laws, certain offshore activities, and other activities that Agencies determine would promote and protect the safety and soundness of banking entities and U.S. financial stability. See 12 U.S.C. § 1851(d)(1). For a full list, see Council Financial Stability Oversight, Study \& Recommendations on Prohibitions on Proprietary Trading \& Certain Relationships with Hedge Funds and Private Equity Funds, 2011)

${ }^{57}$ Ibid

${ }^{58} 12$ U.S.C. $\S 1851(\mathrm{~d})(2)(\mathrm{A})$.

${ }^{59}$ The Investment Company Act of 1940,15 U.S.C. $\S 80 \mathrm{a}-1$ et seq.

${ }^{60} 12$ U.S.C. $\S 1851(\mathrm{a})(1)(\mathrm{B})$.

${ }^{61}$ Financial Stability Oversight, Study \& Recommendations on Prohibitions on Proprietary Trading \& Certain Relationships with Hedge Funds and Private Equity Funds
} 
The Volcker Rule's prohibitions on the banking entities' relationships with hedge funds are also subject to exceptions. A banking entity is allowed to organize and offer a fund in connection with its bona fide trust, fiduciary, and investment advisory services. ${ }^{62}$ Under the Volcker Rule, a banking entity can offer prime brokerage services to hedge funds or private equity funds in which affiliated hedge funds of the banking entities have taken interest subject to the 'arm's length' requirements of the sections 23B of the Federal Reserve Act. Furthermore, since offering prime brokerage services is neither considered as sponsoring nor investing in hedge funds, by no means does the Volcker Rule prohibit a banking entity from offering prime brokerage services to independent hedge funds and private equity funds. ${ }^{63}$

As one of the exceptions to the Volcker Rule, taking or retaining a 3\% or lower de minimis investment in a hedge fund or private equity fund that the banking entity organizes or offers in connection with bona fide trust, fiduciary and investment advisory functions is permitted subject to certain limitations and conditions. ${ }^{64}$ The amount of the de minimis investment should be immaterial to the banking entity and should at most comprise up to $3 \%$ of the total ownership interest of such a fund following an initial one-year seeding period; namely, after one year from the fund's establishment. Within the one-year seeding period, the banking entity is allowed to provide even up to $100 \%$ of the capital of hedge funds or private equity funds. ${ }^{65}$ However, the aggregate of all the interests of the banking entity in all hedge and private equity funds should not exceed $3 \%$ of the Tier 1 capital of the banking entity. ${ }^{66}$

The Volcker Rule further prohibits a banking entity, which serves as an investment manager, or adviser, or sponsor to a hedge or private equity fund and any affiliate of such entity, from entering into a 'covered transaction' as defined in Section 23A of the Federal Reserve Act. ${ }^{67}$

\footnotetext{
6212 U.S.C. $\S 1851(\mathrm{~d})(1)(\mathrm{G})$

${ }^{63}$ Council, Study \& Recommendations on Prohibitions on Proprietary Trading \& Certain Relationships with Hedge Funds and Private Equity Funds

${ }^{64}$ The first condition to be met is that such investment should be for the purposes of establishing the fund, and the second is that the investment should be a de minimis investment.

6512 U.S.C. $\$ 1851(\mathrm{~d})(4)(\mathrm{B})(\mathrm{ii})(\mathrm{I})$.

${ }^{66} 12$ U.S.C. $\S 1851(\mathrm{~d})(4)(\mathrm{B})(\mathrm{ii})(\mathrm{II})$.

${ }^{67} 12$ U.S.C. $\S 1851$ (f). A ‘covered transaction' includes making loans, purchasing assets, extending guarantees, etc. (12 C.F.R. 223.3(h) (Regulation W)) Section 1851(f)(2) of the Volcker Rule requires that in general: "No banking entity that serves, directly or indirectly, as the investment manager, investment adviser, or sponsor to a hedge fund or private equity fund, or that organizes and offers a hedge fund or private equity fund pursuant to paragraph $(d)(1)(G)$, and no affiliate of such entity, may enter into a transaction with the fund, or with any other hedge fund or private equity fund that is controlled by such fund, that would be a covered transaction, as defined in section $371 \mathrm{c}$ of this title [12 U.S.C. 371c], with the hedge fund or private equity fund, as if such banking entity and the affiliate thereof were a member bank and the hedge fund or private equity fund were an affiliate thereof." 12 U.S.C. $\S 1851(f)(1)$.
} 
Section 23A of the Federal Reserve Act imposes strict qualitative and quantitative restrictions on 'covered transactions' between a banking entity and an affiliate. ${ }^{68}$

In addition, section 23B imposes 'arm's length' requirements on the terms of any transaction between a banking entity which organizes or offers or sponsors a hedge or private equity fund or acts as their investment manager or adviser to the hedge or private equity fund. The arm's length requirement means that none of the financial transactions between a banking entity and an affiliate should be more favorable than market terms. Such restrictions are particularly effective in reducing the opportunities for conflicts of interest and transfer of banks' subsidies to hedge funds. ${ }^{69}$

\section{Alternative investment fund regulation in the $\mathbf{E U}$}

The Directive (2011/61/EU) of the European Parliament and the Council was adopted on June 8, 2011 on Alternative Investment Fund Managers, published in the Official Journal of the European Union on July 1, 2011 and entered into force twenty days thereafter (July 21, 2011). ${ }^{70}$ This Directive is the first attempt to regulate hedge funds at the EU level. It is a sweeping regulation, which includes hedge funds, private equity funds, real-estate funds, and infrastructure funds under the brand name of the Alternative Investment Funds (AIFs).

${ }^{68}$ Section $23 \mathrm{~A}$ includes two quantitative and two qualitative rules:

1. A bank's total covered transactions with an affiliate should not exceed $10 \%$ of the banks' total capital.

2. The total amount of the bank's covered transactions with all affiliates combined should not exceed $20 \%$ of the bank's capital.

3. Any extension of credit should be fully secured by the qualifying collateral. The value of the collateral should be between $100 \%$ and $130 \%$ of the amount of the covered transactions.

4. A bank cannot purchase a low-quality asset from an affiliate.

${ }^{69}$ Financial Stability Oversight, Study \& Recommendations on Prohibitions on Proprietary Trading \& Certain Relationships with Hedge Funds and Private Equity Funds. Similar to the limitations on permitted activities under the proprietary trading provisions, the Volcker Rule accommodates limitations on the permitted activities under the provisions prohibiting certain business relationship of banking entities with hedge funds. Indeed, the same statutory 'backstops' for the permitted activities with respect to proprietary trading equally applies to permitted activities under the provisions limiting the business relationship of banking entity with hedge and private equity funds. These statutory backstops involve the circumstances under which the permitted banking entity's relationships with hedge and private equity funds result in a material conflict of interest, material exposure to high-risk assets or high-risk trading strategies, a threat to the safety and soundness of the banking entity, or a threat to the U.S. financial stability. 12 U.S.C. $\S 1851(\mathrm{~d})(2)$.

${ }^{70}$ In most parts, the AIMFD is the equivalent of the Title IV of the hedge-fund related provisions of the U.S. Dodd-Frank Act. 
In addition, following the Liikanen report, ${ }^{71}$ a proposal on banking structural measures striving to improve the resilience of the EU credit institutions was published on January 29, 2014. ${ }^{72}$ The EU proposal on banking structural reforms, which is rightly viewed as the equivalent of the U.S. Volcker Rule, lays down rules aimed at imposing structural changes on too-big-toofail (TBTF) banks by setting restrictions on banks' proprietary trading ${ }^{73}$ and requiring separation of their commercial banking activities from their trading activities. ${ }^{74}$ However, since the EU proposal is yet to become part of the law of the land in the EU, this article will not investigate the proposal. ${ }^{75}$

\subsection{AIFMD's objectives: Systemic risk or investor protection?}

Prior to the global financial crisis of 2007-09, the hedge fund industry was not regulated at the EU level. Instead, hedge funds were subject to regulations of the competent authorities of the Member States at the national level. ${ }^{76}$ However, even at that time, there were concerns about hedge funds' role in financial markets and especially in the corporate governance of nonfinancial companies. ${ }^{77}$ Despite the fact that the European hedge funds, and in general, European

${ }^{71}$ Erkki Liikanen, High-level Expert Group on reforming the structure of the EU banking sector: Final report, 2012)

${ }^{72}$ European Commission, Proposal for a Regulation of the European Parliament and of the Council on structural measures improving the resilience of EU credit institutions, $\operatorname{COM}(2014), 43$ final, available at: http://eurlex.europa.eu/legal-content/EN/TXT/PDF/?uri=CELEX:52014PC0043\&from=EN

Aside from the EU proposal and the U.S. Volcker Rule passed in 2010, main jurisdictions in the EU have already established structural measures for the banking industry. Part 1 of the UK Financial Services (Banking Reform) Act 2013 entitled "Ring-fencing", introduced on December 18, 2013 pursuant to the proposals of the Vickers Commission, and the initiatives by German and French governments to impose banking structural measures are examples of such reforms. The main aim of these regulatory reforms was to mitigate the externalities of the crisis in banking and financial institutions and to minimize the likelihood of recurrence of such crises in the future. See The French law on the separation and regulation of banking activities dated July 26, 2012, and German Banking Separation Bill (Trennbankengesetz) dated February 6, 2013. Since the scope of this article is limited to the hedge fund regulation at the EU level, the initiative at the Member State level will not be studied.

${ }^{73}$ See 12 U.S.C. $\S 1851(\mathrm{~h})(4)$.

${ }^{74}$ This proposal is viewed as an instrument introducing measures to complete the ambitious legal scheme of creating the European Banking Union. The EU regulators pursue several objectives from creating a banking union among which breaking the vicious circle between banks and sovereign debt, preventing banking instability, and ensuring that restoring stability in financial institutions does not require spending from the taxpayers' money, are the most pronounced. The EU Volcker Rule is also said to be a mix of the Volcker Rule-lite plus a form of UK ring-fencing (lite). See Shearman \& Sterling LLP, Comparison of New EU Proposals on Proprietary Trading and Ring-fencing Against US, UK, French and German Rules (2014) 2

${ }^{75}$ For a comparative study of banking structural reforms in major financial centers, see Matthias Lehmann, 'Volcker Rule, Ring-Fencing or Separation of Bank Activities-Comparison of Structural Reform Acts Around the World' (2014) ; Leonardo Gambacorta and Adrian Van Rixtel, 'Structural bank regulation initiatives: approaches and implications' (2013) BIS Working Paper

${ }^{76}$ For more details about hedge fund regulation prior to the Alternative Investment Fund Managers Directive (AIFMD), see Athanassiou, Hedge Fund Regulation in the European Union: Current Trends and Future Prospects; See also Commissions International Organization of Securities, The Regulatory Environment for Hedge Funds, A Survey and Comparison, Final Report, 2006)

${ }^{77}$ For example, hedge funds and private equity funds were harshly criticized by German politicians especially subsequent to thousands of job losses at Gröhe, a German tap maker. See Martin Arnold, 'Hedge fund rules 
AIF industry, witnessed a dramatic growth in recent years, compared to the size of the worldwide hedge fund industry, its size remains modest. ${ }^{78}$ The overall AUM of the European AIFs, of which hedge funds are a portion, amounted to $€ 2.2$ trillion at the end of September 2011. ${ }^{79}$ However, according to the estimates of Eurekahedge in 2010, the size of the European hedge fund industry (exclusive of other AIFs) ${ }^{80}$ was $\$ 340$ billion, and the number of European funds stood at 3,401. ${ }^{81}$ According to Eurohedge, the asset size of the European hedge fund industry has reached $\$ 497.1$ billion in June $2015 .{ }^{82}$ Therefore, it seems that despite the

defended by French MEP' Financial Times (<http://www.ft.com/intl/cms/s/0/ff2c38ca-6111-11df-9bf000144feab49a.html\#axzz2Ss3VFrPH> accessed May 16; See also Richard Milne, "Locusts' of private equity help Grohe' Financial Times (<http://www.ft.com/intl/cms/s/0/7d885ddc-331c-11dd-8a250000779fd2ac.html\#axzz2VVZwbTKb> accessed June 5.

For concerns about job losses due to the activities of private equity funds, See Ieke Van den Burg and Poul Nyrup Rasmussen, Hedge Funds and Private Equity: A Critical Analysis (2007) 111

For concerns about hedge fund activism and their campaign against Deutsche Börse, the Frankfurt stock exchange group, derailing Deutsche Börse's London Stock Exchange (LSE) bid, See Carter Dougherty, 'Hedge funds derailed Deutsche Börse LSE bid' the New York Times (<http://www.nytimes.com/2005/03/07/business/worldbusiness/07iht-boerse.html?pagewanted=all\&_r=0> accessed March 8

Such activisms on the part of hedge funds and private equity funds raised calls from German government to regulate hedge funds at the EU level. In the EU, German and French governments have long been critical of hedge funds as vultures of capitalism, and contradictory to the German idea of 'patient capital' and France's 'managed' capitalism. See Buckley and Howarth, 'Internal Market: Regulating the So-Called 'Vultures of Capitalism'; Klaus C. Engelen, 'Blinking Left, Driving Right' (2005) 19 International Economy 56 56. See also Vivien A. Schmidt, The futures of European capitalism (Oxford University Press 2002)

Given the effects of hedge funds and private equity funds on the firms' corporate governance, which allegedly loosened the ties between financial sector and the industrial sector (by engaging in activities such as empty voting) in continental Europe, these countries supported the AIFMD to limit the activities of hedge funds and private equity funds. See Quaglia, 'The 'Old' and 'New' Political Economy of Hedge Fund Regulation in the European Union'

${ }^{78}$ According to some estimates, no more than 1,785 private equity firms were operating within the EU in 2009. Coupled with the hedge fund industry, they together generate $€ 9$ billion in tax revenue in 2008 . The number of the employees of the private equity firms in Europe in 2008 amounted to 40,000 people. The UK's share is the greatest amounting to 18,000. In addition, private equity firms invested around $€ 51$ billion in European companies in 2008. See Mats Persson, The EU'S AIFM Directive: Likely Impact and Best Way Forward, , 2009)

${ }^{79}$ This number constitutes about $18 \%$ of the EU's GDP. It is also estimated that around $68 \%$ of the assets of AIFs are held by institutional investors among which $70 \%$ are pension funds and insurance companies. See European Commission, Commission Staff Working Document Impact Assessment, Accompanying the document, Commission Delegated Regulation supplementing Directive 2011/61/EU of the European Parliament and of the Council with regards to exemptions, general operating conditions, depositories, leverage, transparency and supervision, 2012) 4

${ }^{80}$ It should be emphasized that the term Alternative Investment Fund is broader than hedge funds and includes entities such as private equity funds, venture capital funds, real estate funds, and investment trusts. Though all hedge funds are considered AIFs, not every AIF is a hedge fund.

${ }^{81}$ However, it is estimated that the combined assets of the investment fund market in Europe, namely the market for UCITS and non-UCITS, in the fourth quarter of 2012 to the yearend amounted to $€ 8,944$ billion. At the end of December 2012, around 70 percent (€6,295 billion) of that amount was invested in UCITS, and the remaining 30 percent in non-UCITS. See Fund The European and Association Asset Management, Quarterly Statistical Release: Trends in the European Investment Fund Industry in the Fourth Quarter of 2012 and Results for the full Year 2012, 2013) 11. Given these numbers, it seems that given the size of the hedge fund industry in Europe, it attracted a disproportionate level of attention from regulators seeking to respond to the financial crisis.

82 , 'European Hedge Fund Assets Grow by 5\% in First Half' (Hedge Fund Intelligence, 2015) $<$ http://www.hedgefundintelligence.com/Article/3500701/EuroHedge-Industry-Analysis-Archive/Europeanhedge-fund-assets-grow-by-5-in-first-half.html $>$ accessed March 7. Given that the hedge funds operating in the EU can hardly be considered systemically important, the EU regulation of hedge funds was partly motivated by 
insignificance of the size of the hedge fund industry, excluding other AIFs, and despite the fact that one of the main concerns throughout the regulatory process was the EU's premature and disproportionate reaction on the assumption of systemic importance of hedge funds, ${ }^{83} \mathrm{EU}$ regulators opted for hedge fund regulation.

The fact that the systemic risk channels through the interconnections of financial institutions and markets, and that it can be amplified by higher leverage, implies that hedge fund regulation should primarily target hedge funds' counterparties and particularly their creditors who are the main providers of leverage to hedge funds. In light of such an insight and based on the motives and the underlying reasons of the enactment of the AIFMD, it was expected that the AIFMD's focus be on hedge funds' interconnectedness with LCFIs. However, the AIFMD only marginally focuses on hedge funds' counterparties and the indirect regulation of hedge funds. Instead, regulatory measures chosen to address potential systemic externalities of hedge funds took the form of direct regulation of hedge funds themselves (AIFs) or of their managers (AIFMs). ${ }^{84}$

A further significant difference between the EU and the U.S. hedge fund regulation is rooted in the basic underlying objectives of these two systems of financial regulation. In addition to investor protection and systemic risk concerns, European financial regulation has a third objective, which is the creation of a single European market to ensure free movement of goods, persons, services, and capital. ${ }^{85}$ This objective is largely pursued by harmonization of laws at the EU level. Accordingly, the prevailing goal in the AIFMD is to provide an EU-wide consistent regulatory and supervisory framework for AIFMs. ${ }^{86}$ To accomplish this goal, the

incidents of fraud in hedge funds which resulted in losses to European investors (e.g., Madoff scandal). As a result, the EU regulatory approach focuses mainly on investor protection issues rather than systemic risk concerns. In contrast, in the U.S., the systemic risk concerns were the driving force behind the regulation of hedge funds. See Eric Helleiner and Stefano Pagliari, The End of Self-Regulation? Hedge Funds and Derivatives in Global Financial Governance (2009) 133

${ }^{83}$ Eilís Ferran, 'After the Crisis: The Regulation of Hedge Funds and Private Equity in the EU' (2011) 12 European Business Organization Law Review 379 398. However, it should be highlighted that the share of the non-UCITS (other AIFs other than hedge funds) which is governed and regulated by the AIFMD is far from insignificant. On the other hand, in Europe, geographic distribution of hedge funds is not even. Some jurisdictions, particularly the UK, have the biggest share of the hedge fund industry (around 80\%), and also other jurisdictions such as Luxembourg and Switzerland, given the size of their economy have a disproportionate number of hedge funds.

${ }^{84}$ Giorgio Tosetti Dardanelli, 'Direct or Indirect Regulation of Hedge Funds: A European Dilemma' (2011) European Journal of Risk Regulation 463475.

${ }^{85}$ See R. Daniel Kelemen, Eurolegalism: the transformation of law and regulation in the European Union (Harvard University Press 2011) 93. See also Tanja Boskovic, Caroline Cerruti and Michel Noel, Comparing European and U.S. Securities Regulations: MiFID Versus Corresponding U.S. Regulations, vol World Bank Working Paper No. 184 (World Bank Publications 2010) 14

86 Commission, Commission Staff Working Document Impact Assessment, Accompanying the document, Commission Delegated Regulation supplementing Directive 2011/61/EU of the European Parliament and of the 
AIFMD takes a step forward and provides legal underpinnings for a single market for AIFMs by establishing a high level of investor protection in the Union. ${ }^{87}$ However, in the U.S. such an objective had already been attained in the 1930s. ${ }^{88}$ Therefore, despite the fact that addressing systemic risk was the impetus for regulating EU hedge funds at the EU level, this goal only constituted a secondary objective for the hedge fund regulation in the EU. ${ }^{89}$

The AIFMD imposes greater degrees of direct regulation and supervision on AIFs or their managers than its counterpart in the U.S. ${ }^{90}$ Indeed, the most significant difference between the U.S. and the EU regulatory measures is the extent to which the AIFMD exercises direct regulatory control over fund managers. Such divergent paths are especially apparent in Article 7 of the AIFMD, which grants enormous powers to the competent regulatory authorities of AIF's home Member States. This article specifically grants the power to the Member States'

Council with regards to exemptions, general operating conditions, depositories, leverage, transparency and supervision

${ }^{87}$ Ibid

${ }^{88}$ The goal of creating a single market in financial products can easily be spotted in many parts of the Directives regarding the EU securities regulation. For example, recital 2 of the 2004/39/EC Directive states this objective and clearly demonstrates how it sees a higher level of investor protection as a means to achieve such an end. It clearly states that "it is necessary to provide for the degree of harmonization needed to offer investors a high level of protection and to allow investment firms to provide services throughout the Community."

${ }^{89}$ It might be the case that the EU regulators seized the opportunity to increase the share of the EU hedge fund industry by providing investor protection and passport mechanisms, rather than addressing systemic concerns which are not justified specifically in case of the EU hedge funds.

Besides these overarching objectives, the AIFMD has more nuanced objectives, such as supervision of financial market players with appropriate authorization and on-going supervision, systemic risk oversight and monitoring macro-prudential risks by competent authorizes, risk management and enhanced management of micro-prudential risks in AIFs by AIFMs, transparency and greater public accountability of the AIFM investing and managing companies, and market efficiency and removal of barriers to efficient cross-border distribution and management of AIFs. See Commission, Commission Staff Working Document Impact Assessment, Accompanying the document, Commission Delegated Regulation supplementing Directive 2011/61/EU of the European Parliament and of the Council with regards to exemptions, general operating conditions, depositories, leverage, transparency and supervision.

In hedge fund regulation regimes, the investor protection concerns are traditionally achieved through restricting retail investors' access to hedge funds. Indeed, such investor protection schemes can also contribute to financial stability. Since accredited and sophisticated investors can protect themselves from fraud and most investment risks, investing in markets dominated by sophisticated investors potentially ensures that the systemic risks through credit channels will be mitigated. This is mostly due to the fact that they can ensure that the entities in which they invest or to which they have exposures are safe and sound and the risks of failures are minimal. Such a capability can mitigate the contagion of systemic risks through direct credit channel. On the other hand, assuming that the accredited investors - mainly composed of institutional investors - are best equipped to check the safety and soundness of their counterparties, the systemic risks through market channels can be reduced as well, due to the fact that they can ensure that their counterparties are well managed and their levels of leverage are reasonable. Such a market limit on leverage would ensure that these counterparties will not be subject to fire sales subsequent to margin calls. Therefore, entry limits for non-accredited investors not only can serve the investor protection purposes, but also it can indirectly serve the systemic stability in the shadow banking sector and mitigate the systemic risk of hedge funds. See Alexander Goodenough, 'Dodd-Frank: Regulating Systemic Risk in the Offshore Shadow Banking Industry' (2011) George Mason Journal of International Commercial Law 137149

${ }^{90}$ Michael McDonald, 'Containing Systemic Risk: New Developments in Trans-Atlantic Hedge Fund Regulation' (2011) 34 Loyola of Los Angeles International and Comparative Law Review 237261 
regulatory authorities to restrict the scope of the fund managers' authorization by setting direct limitations on the fund's investment strategies. ${ }^{91}$

\subsubsection{The AIFMD: Authorization and transparency requirements}

Two main regulatory measures are adopted in the AIFMD to address the potential systemic concerns of hedge funds. First, the AIFMD requires managers of hedge funds to disclose information to both investors and competent authorities of the home Member States. ${ }^{92}$ Second, it empowers the competent authorities of the Member States and the European Securities and Markets Authority (ESMA) to monitor and limit the level of leverage of hedge fund managers. ${ }^{93}$

Since addressing systemic risk issues cannot be achieved at the Member State level, the AIFMD requires exchange of information relating to the potential systemic consequences of AIFM activities between regulators. ${ }^{94}$ The AIFMD requires the competent authorities of Member States who are responsible for the authorization and/or supervision of AIFMs to communicate information to the competent authorities of the Member States if that information is relevant to monitoring and addressing the potential implications of the individual or collective activities of AIFMs for the stability of the systemically relevant financial institutions and the orderly functioning of markets in which AIFMs are active. On top of the above requirement, ESMA and the European Systemic Risk Board (ESRB) should be informed.

In addition to registration, ${ }^{95}$ reporting, and leverage requirements, the AIFMD contains provisions that can, among others, address potential systemic risk of hedge funds. These include regulation of risk management incentives by imposing risk limits ${ }^{96}$ and functional and hierarchical separation of risk management and portfolio management functions, ${ }^{97}$ capital requirements, ${ }^{98}$ liquidity requirements, ${ }^{99}$ provisions regulating investment in securitization

\footnotetext{
91 Ibid

${ }^{92}$ For the definition of home and host Member State of the AIF or the AIFMD, See Article 4(1) of the Directive 2011/61/EU.

${ }^{93}$ McDonald, 'Containing Systemic Risk: New Developments in Trans-Atlantic Hedge Fund Regulation'

${ }^{94}$ Article 53 of the Directive 2011/61/EU.

${ }^{95}$ Such registration and disclosure requirements should be for both hedge funds and prime brokers, or either for hedge funds or prime brokers.

${ }^{96}$ Article 44(1), Regulation (EU) No 231/2013.

${ }^{97}$ Article 15 of the Directive 2011/61/EU.

${ }^{98}$ Article 9. of the Directive 2011/61/EU.

${ }^{99}$ Article 16(1) of the Directive 2011/61/EU.
} 
positions, ${ }^{100}$ regulation of remuneration policies, ${ }^{101}$ rules regulating the relationships of depositaries, prime brokers, and hedge funds, ${ }^{102}$ and Rules for valuation. ${ }^{103}$

\subsubsection{Capital Requirements}

As one of the conditions for authorization of the AIFMs, the Directive requires maintaining a minimum amount of initial capital and own funds. AIFMs internally managing AIFs should be required by the Member States to have an initial capital of at least $€ 300.000 .{ }^{104}$ If AIFMs are appointed as external managers of AIFs, they should at least have an initial capital of $€ 125.000 .^{105}$ In addition to the initial own funds, the Directive requires additional own funds adjusted to the value of the portfolio of the funds under management. Namely, if the value of the portfolios of the AIFs managed by the AIFMs exceeds $€ 250$ million, the AIFM is required to provide an additional amount of its own funds equal to $0.02 \%$ of the amount of assets managed in excess of $€ 150$ million. However, the total of the initial capital and the additional amount must not exceed $€ 10$ million. ${ }^{106}$

\subsubsection{Leverage and limits for leveraged funds}

Information on leverage is essential for regulators to monitor systemic risk. ${ }^{107}$ Inadequate disclosure of leverage can inhibit the micro- and macro-prudential supervision of the potential risks posed by AIFs. ${ }^{108}$ Therefore, imposing reporting requirements on hedge funds' leverage is essential to monitoring systemic risk. Indeed, one of the most significant attempts to regulate potential systemic risks of hedge funds in the $\mathrm{EU}$ is the introduction of the leverage requirements by the AIFMD. ${ }^{109}$ The AIFMD offers a very broad definition of leverage. Leverage is defined in the AIFMD as "any method by which the AIFM increases the exposure

\footnotetext{
${ }^{100}$ Article 17 of the Directive 2011/61/EU.

${ }^{101}$ Article 13 of the Directive 2011/61/EU.

${ }^{102}$ Article 21(1) of the Directive 2011/61/EU.

${ }^{103}$ Article 19(1) of the Directive 2011/61/EU.

${ }^{104}$ Article 9 (1) of the Directive 2011/61/EU.

${ }^{105}$ Article 9 (2) of the Directive 2011/61/EU. Another aspect of direct regulation of hedge funds is evident in stricter capital requirements for internally managed funds which amounts to $€ 300.000$. See Dardanelli, 'Direct or Indirect Regulation of Hedge Funds: A European Dilemma'

${ }^{106}$ Article 9 (3) of the Directive 2011/61/EU.

${ }^{107}$ Commission, Commission Staff Working Document Impact Assessment, Accompanying the document, Commission Delegated Regulation supplementing Directive 2011/61/EU of the European Parliament and of the Council with regards to exemptions, general operating conditions, depositories, leverage, transparency and supervision. See also Article 25 Directive 2011/61/EU.

108 Ibid

${ }^{109}$ Jennifer Payne, 'Private Equity and Its Regulation in Europe' (2011) 12 European Business Organization Law Review 559579
} 
of an AIF it manages, whether through borrowing of cash or securities, or leverage embedded in derivative positions or by any other means". 110

The AIFMD requires the AIFMs to set a maximum level of leverage that they may employ on behalf of each AIF they manage. ${ }^{111}$ Setting those leverage limits, the AIFMs should take into account, inter alia, the type of the AIF, the investment strategies of the AIF, the sources of leverage of the AIF, any other interconnectedness or relevant relationship with other systemically important financial institutions, the need to limit the exposure to any single counterparty, the extent to which the leverage is collateralized, the asset-liability ratio, and the scale, nature and extent of the activity of the AIFM on the markets concerned. ${ }^{112}$ The AIFM should also disclose the use of leverage by each AIF under its management on a regular basis. ${ }^{113}$ When hedge fund managers employ "leverage on a substantial basis", additional disclosure requirements will be triggered. ${ }^{114}$

\subsubsection{Risk Management}

The Directive requires AIFMs to establish an adequate risk management system for identifying, measuring, managing, and monitoring risks of each AIF under their management. The Directive further requires functional and hierarchical separation of risk management and portfolio management functions subject to exceptions for small AIFMs at the Member State level when the separation of these two functions is operationally impracticable. ${ }^{115}$ Such functional and hierarchical separation of the risk management function should be ensured throughout the entire hierarchical structure of the AIFM, up to its governing body. ${ }^{116}$

The AIFMs should also conduct stress tests of the risks associated with the investments made by the AIFs under their management, conduct an appropriate, documented and regularly updated due diligence process when investing on behalf of the AIF, and ensure that the risk

\footnotetext{
${ }^{110}$ Article 4(1)(v) of the Directive 2011/61/EU.

${ }^{111}$ Article 15 (4) of the Directive 2011/61/EU. According to this article, the AIFMs should set limits on the extent of the right to reuse collateral (rehypothecation) or "the guarantee that could be granted under the leveraging agreement." This provision is a 'lighter version' of the original restrictions on the leverage proposed by the Commission in its April 2009 proposal, which required limits to be set on the level of leverage that hedge fund managers can employ. Dardanelli, Direct Or Indirect Regulation of Hedge Funds: A European Dilemma, pp. 477-478. These features, accompanied by others make the final Directive less problematic than originally perceived. See Phoebus Athanassiou, 'The AIFM Directive: An Overview of the Final Rules' (2011) 26 Journal of International Banking Law and Regulation 237242

112 Article 15(4) of the Directive 2011/61/EU.

113 Article 23(5) of the Directive 2011/61/EU.

${ }^{114}$ Dardanelli, 'Direct or Indirect Regulation of Hedge Funds: A European Dilemma'

${ }^{115}$ Article 15 of the Directive 2011/61/EU.

${ }^{116}$ Article 42(2), Regulation (EU) No 231/2013.
} 
profile of each AIF they manage corresponds to the size, portfolio structure, and investment strategy and objectives of the AIF as set out in the fund rules and offering documents. In addition, the AIFMD requires the AIFMs to establish specific safeguards against conflicts of interest, to facilitate the independent performance of risk management activities and demonstrate that the risk management process is consistently effective. ${ }^{117}$

\subsubsection{Liquidity Management}

In addition to capital requirements, the AIFMD also regulates hedge fund liquidity. The Directive requires that the AIFMs, for each fund under their management, which is not an unleveraged closed-ended AIF, establish an appropriate liquidity management system and adopt procedures enabling them to monitor the liquidity risks of the AIF, and ensure the compliance of liquidity profile of the investments of the AIF with its underlying obligations. ${ }^{118}$ AIFMs should regularly conduct stress tests, under normal and exceptional liquidity conditions, enabling them to assess and monitor the liquidity risks of the AIF. ${ }^{119}$ AIFMs should also ensure that the investment strategies, liquidity profiles and redemption policies of the AIFs under their management are consistent. ${ }^{120}$

\section{An early assessment}

\subsection{The Private Fund Act and systemically important hedge funds}

In general, the effectiveness of the Dodd-Frank Act in achieving its objectives remains highly controversial. The effects of the newly introduced regulations in the U.S. on the hedge fund industry also remain unclear. For instance, some commentators suggest that the financial world

${ }^{117}$ Article 15(1) of the Directive 2011/61/EU.

The safeguards against conflicts of interest should at least ensure that:

1. The decisions of the risk management function are based on reliable data appropriately controlled by the risk management function.

2. The remuneration of the risk managers reflects the achievement of the objectives linked to risk management function, irrespective of the performance of the sector of the business in which they are engaged.

3. The risk management function is appropriately and independently reviewed to ensure that decisions are made independently.

4. The risk management function is represented in the governing body or the supervisory function at least with the same authority as the portfolio management function.

5. Any conflicting duties are properly segregated. Article 43(1), Regulation (EU) No 231/2013.

118 Article 16(1) of the Directive 2011/61/EU.

${ }^{119}$ Article 16(1) of the Directive 2011/61/EU.

${ }^{120}$ Article 16(2) of the AIFMD. The AIFMD also requires the Commission to adopt by means of delegated acts and measures specifying the liquidity management systems and procedure, and the alignment of the investment strategy, liquidity profile and redemption policies. See Article 16(3) of the Directive 2011/61/EU. 
will be as prone to bailouts as it used to be prior to the Dodd-Frank Act. ${ }^{121}$ Others view potential regulatory arbitrage as the element that can render many regulatory measures of the DoddFrank Act toothless. ${ }^{122}$ Early empirical studies also suggest that the hedge fund industry is not dramatically affected by the new regulatory measures. ${ }^{123}$

Direct method of regulation in the hedge fund industry is primarily used to address the problem of information asymmetry between hedge funds and regulators, or hedge funds and their creditors and investors. This method of regulation, however, can have indirect effects on addressing potential systemic concerns of hedge funds by making the hedge fund industry more transparent. Without registration and disclosure requirements, indirect regulation of hedge funds through their counterparties and creditors would be infeasible due to the fact that without such minimum regulatory measures, regulatory authorities would not be afforded the adequate information needed for indirect regulation of hedge funds. In other words, registration and disclosure requirements are a necessary complement for indirect regulation of hedge funds, ${ }^{124}$ and can help harness market discipline.

Since hedge funds are unlikely to fall under the purview of direct regulation, they will mainly be regulated indirectly. However, there are concerns that market discipline, which will be enforced by hedge fund counterparties and creditors within the indirect-regulation regime, cannot effectively address their potential risks. Particularly, it is argued that the prime brokers are not adequately equipped to monitor the liquidity risks of hedge funds. ${ }^{125}$

Another commendable move by the Private Fund Act is that it takes a laddered regulatory approach to regulation of hedge funds. The benchmark for direct regulation of hedge funds in the U.S. is their size. Hedge funds with less than $\$ 50$ billion in consolidated assets cannot be considered as SINBFCs. ${ }^{126}$ Since the number of advisers exceeding the $\$ 50$ billion AUM subject to regulation is extremely limited, ${ }^{127}$ it is expected that the contingent direct regulation

\footnotetext{
${ }^{121}$ David Skeel, 'Making Sense of the New Financial Deal' (2011) 5 Liberty University Law Review 181182

${ }^{122}$ Alison K. Gary, 'Creating A Future Economic Crisis: Political Failure and the Loopholes of the Volcker Rule' (2012) 90 Oregon Law Review 13391349

${ }^{123}$ Wulf A. Kaal, 'Hedge Fund Manager Registration under the Dodd-Frank Act' (2013) 50 San Diego Law Review 243

${ }^{124}$ Dardanelli, 'Direct or Indirect Regulation of Hedge Funds: A European Dilemma'

${ }^{125}$ Nabilou and Pacces, 'The Hedge Fund Regulation Dilemma: Direct vs. Indirect Regulation'

${ }^{126}$ The consolidated assets of the LTCM were \$125 billon at its peak. There might be instances that even smaller hedge funds might be considered as such.

127 As of 2012, only four hedge funds out of 50 hedge funds, which are registered pursuant to the Dodd-Frank Act, exceed the $\$ 50$ billion threshold. Therefore, the number of advisers exceeding the limit will be very limited. The Managed Funds Association (MFA), a hedge fund industry association, estimates that applying the thresholds of the $\S 113$ of the Act, it is highly unlikely that any hedge fund would be designated as a SINBFC.
} 
will be of a very limited impact on hedge funds and their liquidity. ${ }^{128}$ In addition, the advisers who are approaching the threshold may divest of some assets to avoid being designated as SINBFC. Such a regulatory strategy is well designed to push the hedge funds, which are in the periphery of the financial system, not to approach to the apex of the system. If the prudential regulation by the Federal Reserve would be optimally priced, it will decrease the probability that the law would apply to them with considerable elasticity. ${ }^{129}$

The dark side of the laddered regulatory approach is that it is based on hedge funds' size. A regulatory regime relying on size-thresholds is unlikely to address the risks arising from a large number of hedge funds' potential herd behavior. Since the Dodd-Frank Act is opted for firmby-firm designation of hedge funds as SINBFCs, it is unlikely that it can address the herd behavior of small and mid-sized hedge funds. ${ }^{130}$ The bright side of such a regulatory strategy, however, is that it will induce hedge funds to reduce their size to avoid being designated as SINBFC and ensuing heavier and costlier regulation. As mentioned earlier, this strategy in fact discourages firms from getting closer to the apex of the financial system. ${ }^{131}$ Few hedge funds will be designated as SINBFCs and become subject to the direct regulations of the Fed. Most hedge fund leverage and liquidity regulation will rest with the prime brokers, which in turn are regulated by the Federal Reserve.

One of the policy relevant aspects of hedge fund regulation relates to the transient nature of hedge funds. ${ }^{132}$ Structurally and organizationally, banks are capable of developing robust and complex regulatory compliance department, because they have longer life-expectancy and there are considerable economies of scale in banks' regulatory costs. ${ }^{133}$ Whereas taking account

\footnotetext{
${ }^{128}$ Dixon Lloyd, Noreen Clancy and Krishna B. Kumar, Hedge Funds and Systemic Risk (RAND Corporation 2012) 92

${ }^{129}$ For the concept of elasticity of law and periphery and apex (hierarchy in the financial system), See Katharina Pistor, 'A legal theory of finance' (2013) 41 Journal of Comparative Economics 315; Dan Awrey and Katharina Pistor, An Overview of the Legal Theory of Finance (2014).

${ }^{130}$ To mitigate such risks, the Dodd-Frank Act grants discretion to financial regulators such as the Securities and Exchange Commission (SEC) and the Commodity Futures Trading Commission (CFTC) to address industry-wide liquidity issues.

${ }^{131}$ Pistor, 'A legal theory of finance'

${ }^{132}$ It is estimated that average life span of a hedge fund is 40 months. $60 \%$ of hedge funds disappear within 3 years and fewer than $15 \%$ of hedge funds last longer than 6 years. See Michael R. King and Philip Maier, 'Hedge Funds and Financial Stability: Regulating Prime Brokers Will Mitigate Systemic Risks' (2009) 5 Journal of Financial Stability 283 286; Burton G. Malkiel and Atanu Saha, 'Hedge funds: Risk and return' (2005) 61 Financial analysts journal 80; Stephen J. Brown, William N. Goetzmann and Roger G. Ibbotson, 'Offshore Hedge Funds: Survival and Performance, 1989-95' (1999) 72 The Journal of Business 91

${ }^{133}$ See Joseph P. Hughes and Loretta J. Mester, 'Who said large banks don't experience scale economies? Evidence from a risk-return-driven cost function' (2013) Journal of Financial Intermediation

However, it is suggested that big banks' profitability might not be attributable to efficiencies in scale, but it should be studied in light of the implicit guarantees offered to too-big-to-fail banks. As mentioned earlier, the distortive effect of these guarantees is such that some mergers in the banking sector were motivated by achieving too-big-
} 
of higher attrition rates ${ }^{134}$ in the hedge fund industry, it might not be optimal to force shortlived and relatively small hedge funds to develop regulatory compliance departments. ${ }^{135}$ Such regulatory requirements can damage start-up and small hedge funds disproportionately. ${ }^{136}$

Last but not certainly least, what matters most in financial reporting is timing, and it is not clear whether regulators react to information as quickly as markets do, or quickly enough to have an impact on countering systemic risk. Given the inherent sluggishness of regulation and legal processes, it is highly unlikely that regulators can use disclosed information by hedge funds to mitigate concerns about systemic risk and financial instability.

\subsection{The Volcker Rule}

In addition to its three main objectives, i.e., addressing interconnectedness, conflicts of interest and cross-subsidization problems, the Volcker Rule should also avoid putting U.S. banks in competitive disadvantage in global markets dominated by universal banks. ${ }^{137}$ It is clear that achieving all these often-competing objectives is the greatest challenge of the Volcker Rule.

In terms of achieving these objectives, the Volcker Rule was only partially successful; the first reason being the political compromises made in the process of legislation. Indeed, Paul Volcker himself is quoted saying that the bill (containing the Volcker Rule) "went from what is best to what could be passed" in the process of its enactment. ${ }^{138}$ The most striking of these compromises are best depicted in the extensive exceptions to the provisions of the Volcker Rule, which made it practically toothless. ${ }^{139}$ Facing such exceptions, even Paul Volcker himself admits that the success of the Volcker Rule depends much on the way it is going to be implemented. ${ }^{140}$

\footnotetext{
to-fail status and gaining access to implicit government guarantees. See Elijah Brewer, III and Julapa Jagtiani, 'How Much Did Banks Pay to Become Too-Big-To-Fail and to Become Systemically Important?' (2013) 43 Journal of Financial Services Research 1

${ }_{135}^{134}$ Attrition rate refers to rate of shrinking in the number of hedge funds due to hedge fund closures.

${ }^{135}$ Lloyd, Clancy and Kumar, Hedge Funds and Systemic Risk

${ }^{136} \mathrm{Kaal}$, 'Hedge Fund Manager Registration under the Dodd-Frank Act'

${ }^{137}$ Gary, 'Creating A Future Economic Crisis: Political Failure and the Loopholes of the Volcker Rule'ibid

${ }^{138}$ Louis Uchitelle, 'Volcker Pushes for Reform, Regretting Past Silence' the New York Times (10, 2010)

$<$ http://www.nytimes.com/2010/07/11/business/11volcker.html?pagewanted=all\&_r=2\&>

${ }_{139}$ Gary, 'Creating A Future Economic Crisis: Political Failure and the Loopholes of the Volcker Rule'

${ }^{140}$ Uchitelle, 'Volcker Pushes for Reform, Regretting Past Silence'
} 
In addition to the political compromises, one of the key aspects of the implementation of the Volcker Rule is how to distinguish permitted activities from prohibited activities. ${ }^{141}$ The problem of distinguishing such activities ultimately boils down to a definitional problem. ${ }^{142}$ Future definitions of the key terms in the Volcker Rule will play a major role in minimizing the risk of evasion of the Volcker Rule's provisions. ${ }^{143}$ The question is whether regulators would be able to create mechanisms to distinguish prohibited activities from permitted activities that share common features. Given that regulators have already tried and failed to appropriately define proprietary trading in 2005, and have come to the conclusion that preventing proprietary trading requires a subjective and case-by-case evaluation, ${ }^{144}$ the future definitions might fare no better. Since such an assessment will often require a case-by-case analysis of the activities, it is not known what the costs of such assessments would in practice be. Furthermore, it remains to be seen what the response could be should the costs of such caseby-case assessments exceed their benefits.

In addition to the definitional problems, the success of the Volcker Rule, depends on its future implementation by regulatory agencies. For example, one of the provisions of the Volcker Rule containing an exception, which is considered as a loophole, involves permitting de minimis investment of banking entities in a hedge fund up to $3 \%$ of bank's Tier 1 Capital. Though essential for the viability of the hedge fund industry, banks and hedge funds can potentially exploit this exception. Moreover, the Volcker Rule permission for a banking entity to serve as a general partner, managing member, or trustee of a hedge fund, or to have controlling interest in a hedge fund, ${ }^{145}$ can be seen as another potential loophole that hedge funds can exploit, which may eventually result in putting banking entities at risk. Although it is suggested that an

\footnotetext{
${ }^{141}$ Darrell Duffie, Financial Regulatory Reform after the Crisis: An Assessment (2016) 20; Anjan Thakor, 'The Economic Consequences of the Volcker Rule' (Summer 2012) US Chamber of Commerce's Center for Capital Market Competitiveness 11

${ }^{142}$ For example, one of the major concerns about the Volcker Rule is the concern about its unintended consequences with respect to the definitions particularly regarding the terms 'hedge fund', 'private equity fund', 'proprietary trading', 'market making', 'hedging', and 'customer-driven transactions'. Inappropriate definitions of such terms might have adverse systemic impact on financial institutions, particularly on their liquidity management. See also Hossein Nabilou, 'Bank Proprietary Trading and Investment in Private Funds: Is the Volcker Rule a Panacea or Yet Another Maginot Line?' (Forthcoming 2017) 32 Banking and Finance Law Review ${ }^{143}$ Indeed, there is an ample need for definitions in the Volcker Rule. For example, the Volcker Rule only allows banking entities to offer organized or sponsored funds only to 'customers' of a banking entity. In this respect, there is a need for a definition of the word 'customer' in order not to allow all its clients and counterparties to take advantage of the term 'customer'. As an additional example, the de minimis exception applies in two cases. It is applied "to restrict the exposure of a banking entity to $3 \%$ of any single fund" and also to limit the banking entity's aggregate exposure to $3 \%$ of its Tier 1 capital. In both cases, calculating the de minimis investment will pose a challenge to regulators. See Council, Study \& Recommendations on Prohibitions on Proprietary Trading \& Certain Relationships with Hedge Funds and Private Equity Funds

${ }_{144}$ K. Sabel Bradley, General Accountability Office Struggles with Dodd-Frank's Volcker Rule (2011)

${ }^{145} 12$ U.S.C. $\S 1851(\mathrm{~d})(1)(\mathrm{G})$.
} 
outright prohibition of bank involvement in hedge funds is the best way that can prevent losses to the banking entity emanating from hedge funds, ${ }^{146}$ such a general ban could inhibit many benefits that hedge funds deliver to banks and vice versa.

An additional concern is that regulation of hedge funds in the U.S. might give rise to regulatory arbitrage and potential exodus of hedge funds to regulatory safe havens or other jurisdictions with lightly regulated markets. For example, pursuant to the enactment of the Volcker Rule, some activities may move to the shadow banking sector, ${ }^{147}$ because of the increased regulatory costs to banks. ${ }^{148}$ Therefore, the Volcker Rule may relocate the proprietary trading activities from highly regulated banks to lightly regulated hedge funds. ${ }^{149}$ Although preventing banking entities from engaging in proprietary trading by subsidized funds is the very objective of the Volcker Rule, as an unintended consequence, the Rule relocates the proprietary trading to lightly regulated financial institutions. In addition, it is likely that the exodus of proprietary trading might happen from the U.S. banks to non-U.S. banks and financial institution if, compared to other main jurisdictions, the costs of implementation of the Volcker Rule for the regulated firms exceed the potential benefits that such regulation confers. ${ }^{150}$ In this case, it seems that the costs far outweigh the benefits (if any) to financial institutions.

However, given the current coordination between regulators, and more interventionist approach taken in the EU, the likelihood of systematic regulatory arbitrage by hedge funds is not significant. Such concerns are at least partially ameliorated, because after the global financial crisis most shadow banks, including hedge funds, became subject to regulation under the Dodd-Frank Act in the U.S. and the AIFMD in the EU. Moreover, there is considerable pressure on offshore jurisdictions such as the Cayman Islands and the British Virgin Islands to tighten their regulation of hedge funds to prevent regulatory arbitrage.

\footnotetext{
${ }^{146}$ Gary, 'Creating A Future Economic Crisis: Political Failure and the Loopholes of the Volcker Rule'

${ }^{147}$ The shadow banking system (also known as securitized banking) is a system of credit intermediation involving activities and institutions outside the traditional banking system. See Financial Stability Board, Progress in the Implementation of the G20 Recommendations for Strengthening Financial Stability: Report of the Financial Stability Board to G20 Finance Ministers and Central Bank Governors, 2011). It mainly refers to the origination, acquisition, and pooling of debt instruments into diversified pools of loans and financing the pools with short term external debt. See Nicola Gennaioli, Andrei Shleifer and Robert W. Vishny, 'A Model of Shadow Banking' (2011) NBER Working Paper No 1711 .

148 Inci Ötker-Robe and others, 'Impact of Regulatory Reforms on Large and Complex Financial Institutions' (2010) IMF Staff Position Note 26

${ }^{149}$ Charles K. Whitehead, 'The Volcker Rule and Evolving Financial Markets' (2011) 1 Harvard Business Law Review 39

${ }^{150}$ See, for example, Hossein Nabilou, 'Regulatory Arbitrage and Hedge Fund Regulation: A Need for a Transnational Response?' (2017) 22 Fordham Journal of Corporate and Financial Law (forthcoming)
} 
The Volcker Rule is viewed as the Dodd-Frank Act's version of Glass-Steagall's separation of investment banking from commercial banking, and accordingly it is dubbed the Glass-Steagall Lite. ${ }^{151}$ It follows that the Volcker Rule can be subject to most of the criticisms pointed to the Glass-Steagall Act, which culminated in its erosion through time and its repeal in $1999 .{ }^{152}$ For instance, the Volcker Rule's prohibition on proprietary trading might increase systemic risk, because it would not allow banking entities to adequately diversify their risks. ${ }^{153}$

However, the concerns about adverse effects of the Volcker Rule on diversification of banking entities and its overall impact on financial instability is unfounded, because it is only idiosyncratic or firm-specific risk (and not systemic risk) that can be diversified away. ${ }^{154}$ In the same vein, it is argued that although diversification, originating from mixing bank and nonbank activities, can reduce the likelihood of individual banking default, it increases the likelihood of systemic risk. ${ }^{155}$ In other words, the fact that integrated conglomerates composed of both banks and non-banks are financed by risk-insensitive (or information-insensitive) deposits weakens market discipline on their non-bank divisions. Therefore, those divisions will tend to take more risks. Such a conclusion, namely -the cost of mixing traditional banking activities with other financial services within financial holding companies (FHCs) increases the market risk of the firm - is also supported by recent empirical evidence suggesting that diversification gains are more than offset by the costs associated with the exposure to volatile activities. $^{156}$

In addition, since a banking entity's main function is maturity transformation, banks have special cost-advantage in servicing loans to households, small businesses and other industrial sectors, which cannot be easily replicated outside the banking sector. In other words, the bank loans are not substitutable. ${ }^{157}$ Meanwhile, other financial institutions such as hedge funds can

\footnotetext{
${ }^{151}$ Acharya and Richardson, 'Implications of the Dodd-Frank Act'

${ }^{152}$ For a discussion on the pros and cons of the universal banking vs. specialized banking in which commercial banks are kept separate from investment banks, see Georg J. Benston, The Separation of Commercial and Investment Banking: the Glass-Steagall Act Revisited and Reconsidered (Oxford University Press 1990) 179; Anthony Saunders and Ingo Walter, 'Financial architecture, systemic risk, and universal banking' (2012) 26 Financial Markets and Portfolio Management 39.

153 See Gambacorta and Van Rixtel, 'Structural bank regulation initiatives: approaches and implications' (Providing an overview of the economies of scope in banking and discussing whether the Volcker Rule leads to a loss of diversification benefits.)

${ }^{154}$ Acharya and Richardson, 'Implications of the Dodd-Frank Act'

155 Xavier Freixas, Gyöngyi Lóránth and Alan D. Morrison, 'Regulating financial conglomerates' (2007) 16 Journal of Financial Intermediation 479

${ }^{156}$ Kevin J. Stiroh and Adrienne Rumble, 'The dark side of diversification: The case of US financial holding companies' (2006) 30 Journal of Banking \& Finance 2131ibid

${ }^{157}$ Eugene F. Fama, 'What's different about banks?' (1985) 15 Journal of Monetary Economics 29
} 
easily perform proprietary trading. Compared to banks, these financial institutions have less leverage ${ }^{158}$ and do not have access to government safety nets. Therefore, it is argued that the Volcker Rule can be justified on the grounds that non-core banking functions can be performed in less systemically important part of the financial system. ${ }^{159}$

Another criticism based on the analogy of the Volcker Rule with the Glass-Steagall Act is predicated on highlighting the potential forgone efficiencies in terms of economies of scale and scope. ${ }^{160}$ Theory and empirical evidence on optimal size of a banking entity is mixed. On the one hand, the efficient size for a banking entity might be very low. ${ }^{161}$ On the other hand, empirical evidence shows substantial economies of scale in the banking industry. ${ }^{162}$ In addition, it is suggested that big banks' profitability might not be attributable to efficiencies in scale, but it should be studied in light of the implicit guarantees offered to too-big-to-fail banks. The distortive effect of these guarantees is such that achieving too-big-to-fail status and gaining access to implicit government guarantees motivated some mergers in the banking sector. ${ }^{163}$ Therefore, it seems that the objections to the Volcker Rule which aims at prohibiting depository institutions from engaging in proprietary trading or spinning-off their hedge funds and private equity funds on the grounds of diversification and economies of scale and scope are not founded on sound theoretical and empirical evidence.

With respect to prohibiting cross-subsidization of hedge funds through banks, the basic argument for the Volcker Rule is that it is not justifiable to let the financial institutions invest on their own accounts while funding their activities at below-market rates coming from the government explicit and implicit guarantees. ${ }^{164}$ Indeed, in terms of cross-subsidization concerns, the Volcker Rule and its exceptions struck a reasonable balance between preventing such opportunistic behavior (taking advantage of government subsidies) while not stifling the

\footnotetext{
${ }^{158}$ Andrew Ang, Sergiy Gorovyy and Gregory B. van Inwegen, 'Hedge Fund Leverage' (2011) 102 Journal of Financial Economics 102

${ }^{159}$ Acharya and Richardson, 'Implications of the Dodd-Frank Act'

${ }^{160}$ For an overview of the scale and scope economies in financial institutions, See Allen N. Berger, William C. Hunter and Stephen G. Timme, 'The efficiency of financial institutions: A review and preview of research past, present and future' (1993) 17 Special Issue on The Efficiency of Financial Institutions 221

${ }^{161}$ Ibid

${ }^{162}$ Hughes and Mester, 'Who said large banks don't experience scale economies? Evidence from a risk-returndriven cost function'

${ }^{163}$ Brewer and Jagtiani, 'How Much Did Banks Pay to Become Too-Big-To-Fail and to Become Systemically Important?'

${ }^{164}$ This argument equally applies to other financial institutions having access to government subsides such as government-sponsored enterprises (GSEs) (e.g., Fannie Mae and Freddie Mac) and implicitly guaranteed enterprises, such as those perceived to be too-big-to-fail. See Acharya and Richardson, 'Implications of the DoddFrank Act'.
} 
investment of banks in hedge funds and private equity funds particularly in those funds that are in the start-up phase.

With respect to conflicts of interest, the extensive exceptions in the Volcker Rule, both to proprietary trading and investment in hedge funds and private equity funds, though marginally mitigate conflicts of interest, fall short of providing a conflict-of-interest-proof environment for all stakeholders, notably the banking entity, its customers, and hedge funds. However, it remains to be seen how monitoring and management of conflicts of interest will be conducted in practice. ${ }^{165}$

\subsection{Alternative Investment Fund Managers Directive}

Hedge fund regulation in the EU is more concerned with investor protection as a prerequisite for building a European single market for the AIF industry than systemic risk. Therefore, it is not surprising that a large number of articles of the AIFMD are directly or indirectly dedicated to the furtherance of the investor protection objectives as a means to create single market in AIFs rather than addressing systemic risk. ${ }^{166}$ However, this article argues that investor protection concerns of the EU regulators are mostly unfounded, because the investor base of the AIFs consists of professional investors who have the proper means to protect themselves. Therefore, the AIFMD's focus on investor protection in hedge fund regulation can be seen as a misallocation of regulatory resources.

Except in exceptional cases such as rules on depositaries, the Directive is more inclined to regulate hedge funds directly. The direct regulation of hedge funds is consistent with the aim of building a single market for AIFs and investor protection issues; however, it is inconsistent with the aim of regulating potential systemic risk of hedge funds.

In addition to the criticisms directed at the direct regulation of hedge funds in the EU, the AIFMD is criticized on several grounds. First, with respect to the definitions and scope, the AIFMD's attempt to provide an arbitrage-proof definition is criticized due to providing an over-inclusive definition of AIFs. ${ }^{167}$ It also internally fails to differentiate between different

\footnotetext{
${ }^{165}$ Nabilou, 'Bank Proprietary Trading and Investment in Private Funds: Is the Volcker Rule a Panacea or Yet Another Maginot Line?'

${ }^{166}$ Mads Andenas and Iris HY Chiu, 'Financial stability and legal integration in financial regulation' (2013) 38 European Law Review 335. (Arguing that even after the financial crisis the governance of finance in Europe has not moved away from the financial integration objectives toward restoring financial stability, and financial stability concerns have succumbed to the requisites of financial and legal integration.)

${ }^{167}$ Hossein Nabilou, 'The Conundrum of Hedge Fund Definition' (Forthcoming 2016) European Company and Financial Law Review
} 
types of hedge funds. Moreover, regulating hedge funds by size, despite having merits in terms of not overburdening the small and mid-sized hedge funds, is criticized because it fails to acknowledge that one of the most important real concerns about hedge funds originates from their potential herd behavior. ${ }^{168}$

Secondly, imposition of capital, leverage, risk-management, liquidity-management requirements, and restrictions on investment in securitization positions can raise the cost of doing business for hedge funds in the EU. Since the requirements of other major jurisdictions are not as strict as the ones imposed in the EU, the likelihood of regulatory arbitrage increases. Furthermore, imposition of such requirements on hedge funds can deprive financial markets from the benefits of hedge funds, such as their contribution to diversification and liquidity, their contribution to market resiliency, market efficiency, and their role in the price discovery mechanism. In addition, hedge funds' contrarian position taking, their potential role in mitigating the effects of sudden shocks to the financial system, smoothing the market volatility, and reducing the magnitude of asset price bubbles might be compromised.

The most efficient approach to moderate leverage and mitigate its risks lies in the regulatory reform of the banking sector. ${ }^{169}$ Prior to the AIFMD, the International Organization of Securities Commissions (IOSCO) proposed the mandatory registration, regulation and supervision of prime brokers and banks providing leverage to hedge funds to monitor their leverage. ${ }^{170}$ In other words, the IOSCO supported indirect regulation of hedge funds to address the risks arising from their leverage. Nonetheless, the AIFMD opted for direct regulation of hedge fund leverage. In contrast, the U.S. Dodd-Frank Act opts for indirect regulation of hedge funds' leverage through restricting the relationships of the banking entities with hedge funds by introducing the Volcker Rule. ${ }^{171}$

The direct regulation of leverage of hedge funds, as adopted by the AIFMD, can have at least two negative unintended consequences. First, leverage constraints on hedge funds will affect certain types of hedge funds disproportionately. For example, hedge funds specialized in arbitrage-type investment strategies such as convertible arbitrage, fixed-income arbitrage and equity market neutral will severely be affected. Since limits on the level of leverage can

\footnotetext{
${ }^{168}$ Nicole M. Boyson, 'Implicit Incentives and Reputational Herding by Hedge Fund Managers' (2010) 17 Journal of Empirical Finance 283

${ }^{169}$ Bianchi and Drew, 'Hedge Fund Regulation and Systemic Risk'

${ }^{170}$ Ibid

${ }^{171}$ Nabilou and Pacces, 'The Hedge Fund Regulation Dilemma: Direct vs. Indirect Regulation'
} 
potentially limit the expected return on such strategies, it will have a chilling effect on the funds employing these strategies. ${ }^{172}$ Secondly, the impact of direct leverage requirements on financial markets is that the limitations of leverage for arbitrage-based hedge funds will lower the market liquidity and will result in less efficient price discovery mechanisms. As a result, more price distortions and dislocations will remain intact, because less and less capital will be deployed to exploit such inefficiencies. All in all, imposing leverage constraints can make the markets less efficient due to the limits they impose on the ability of hedge funds to employ arbitrage-type strategies. ${ }^{173}$ Therefore, it seems that monitoring leverage is best to be performed by prime brokers.

The bright side of leverage requirements of the AIFMD is that the Directive does not engage in the micro-management of the leverage of hedge funds; instead, it only sets general standards, such as caps for leverage and imposes disclosure requirements on funds' leverage. Indeed, unlike the draft proposal of the AIFMD which attempted to directly regulate hedge-fund leverage, except in exceptional circumstances, the AIFMD delegates the micro-management of leverage to AIFMs. However, regarding leverage requirements, the AIFMD does not focus on the interconnectedness of hedge funds with LCFIs (such as their prime brokers as the main leverage providers of hedge funds), whose knowledge of hedge fund business better place them to monitor hedge funds' risks arising from excessive leverage. ${ }^{174}$

Although EU regulators provide countervailing benefits to European hedge funds, such as passport mechanism and enhanced investor protection to offset the costs of regulation, it is essentially an empirical question to evaluate whether the benefits of hedge fund regulation in the EU will outweigh its costs. An additional benefit that European regulators can offer to hedge funds is to encourage greater retailization of hedge funds. Given the heightened level of investor protection offered by the AIFMD to investors in hedge funds, the Member States can relax the requirements for retail investors to invest in hedge funds. Providing lower standards for investing in hedge funds can attract more hedge funds to the European markets. Such a development has already been ongoing in the U.S. With increasing regulation of hedge funds in the U.S. after the Dodd-Frank Act, the Jumpstart Our Business Startups Act (the JOBS Act) was enacted according to which hedge funds can solicit the general public. However, hedge

\footnotetext{
${ }^{172}$ Bianchi and Drew, 'Hedge Fund Regulation and Systemic Risk'

${ }^{173}$ Ibid

${ }^{174}$ As mentioned earlier, on January 29, 2014, the European Commission proposed a final proposal on structural measures improving the resilience of the EU credit institutions which is the equivalent of the U.S. Volcker Rule.
} 
funds should make sure that only accredited investors invest in their funds. In addition, there are jurisdictions, such as Australia, which do not impose restrictions on retail investments in hedge funds. ${ }^{175}$ It seems that with the level of protection that the AIFMD offers to investors, restrictions on raising capital from retail investors could at least be relaxed.

Overall, the legislative process of the AIFMD suggests that hedge fund regulation in the EU was a politically motivated overreaction to their perceived contribution to financial instability. The main objective of the Directive seems to be the creation of a single market for AIFs rather than addressing systemic risk. The EU regulators' emphasis on the investor protection can also be understood in light of creating a European single market for financial services. Despite the fact that the impetus for the enactment of the AIFMD was the concerns about hedge funds' systemic aspects and their contribution to financial instability, hedge fund regulation in the EU only marginally addressed systemic risk concerns and more in general, the risks that hedge funds can potentially pose to financial stability.

\section{Conclusion}

This article compares hedge fund regulation in the U.S. and the EU; two jurisdictions constituting the biggest centers hosting the hedge fund industry. Although regulatory responses to the perceived contribution of hedge funds to financial instability originated from virtually the same course of events, the final outcome was the emergence of divergent regulatory paths across the Atlantic. This divergence constitutes a great divide in transatlantic regulation with respect to the overarching regulatory strategies towards hedge funds, where the direct regulation of hedge funds is pursued by EU regulators, and indirect regulation by U.S. regulators. Building upon the turmoil of the financial crisis and using it as a pretext for expanding their regulatory turf, EU regulators- primarily concerned with creating a single market for financial services- put forward proposals for hedge fund regulation within which a passport mechanism was embedded. Considering the passport mechanism as a means to achieve creating a single market for AIFs, and backing up the passport mechanism by investor protection mechanisms, the EU regulators introduced the AIFMD. Given the priority of creating a single market for AIFs, systemic risk concerns are only marginally addressed in the AIFMD. In contrast, the main concern in the U.S. still remained to be systemic risk of hedge

\footnotetext{
${ }^{175}$ Jón Daníelson and Jean-Pierre Zigrand, 'Regulating Hedge Funds' in France Banque de (ed), Financial Stability Review; Special Issue, Hedge Funds (Financial Stability Review; Special Issue, Hedge Funds, 2007) 31
} 
fund, which gave birth to the Private Fund Act, the Volcker Rule and the authority granted to the FSOC to designate hedge funds as SINBFC.

On the one hand, such divergent regulatory approaches gave shape to the indirect and lighttouch regulation with a focus on potentially too-big-to-fail hedge funds, the interconnectedness of hedge funds with LCFIs, and the adoption of a laddered regulatory approach to hedge fund regulation in the U.S. On the other hand, in Europe, investor protection concerns engendered a more stringent and direct regulatory framework for hedge funds. Although Europe had the bold idea of leading the way in setting out global standards for hedge fund regulation, its regulatory approach is detrimental to the European hedge fund industry. Europe's crack-down on hedge funds is likely to put them in competitive disadvantage, encourage regulatory arbitrage, and give rise to relocation of the industry to off-shore jurisdictions. Whereas, given the heavy-handed requirements in the EU, it is highly unlikely that regulatory arbitrage, in terms of exodus of U.S. hedge funds to Europe, would be a concern for U.S. regulators.

This article also sheds light on the potential future developments in regulating hedge funds on both sides of the Atlantic. It argues that the EU regulatory policy towards hedge funds, particularly in areas involving the direct regulation of hedge funds originating from investor protection concerns, should be revisited. Instead, the regulatory focus should be shifted towards indirect regulation of hedge funds targeting their interconnectedness with LCFIs and their potential herd behavior. Otherwise, given the heightened level of investor protection offered by the AIFMD to investors in hedge funds, the restrictions on raising capital from retail investors could at least be partially relaxed to offset the regulatory burden and prevent regulatory arbitrage by hedge funds. 